\title{
Eskatologie en koninkryk in die
}

\author{
Markusevangelie
}

\author{
Ernest van Eck \\ Departement Nuwe-Testamentiese Wetenskap \\ Universiteit van Pretoria
}

\begin{abstract}
Eschatology and kingdom in Mark

This article investigates the concepts of eschatology and kingdom in Mark from a narratological point of view. Special attention is given to the narrator's use of story time and plotted time, the narrative function of Mark 13, and the Son of man sayings in the Gospel. The two most important conclusions reached are that Mark uses the Son of man sayings in a non titular way, and that the coming of the son of man (parousia) refers to Jesus' vindication by God at his resurrection. In Mark the kingdom is equated with Jesus' new household, a household that replaces the temple. The concepts of kingdom (new household), eschatology and son of man are thus so closely linked in Mark's narrative that eschatology is the kingdom and the kingdom is eschatology. A possible sociohistorical setting for Mark's community, in which the above understanding of the concepts of kingdom, eschatology and Son of man sayings would have made sense, is also postulated.
\end{abstract}

\section{INLEIDENDE OPMERKINGS}

Die tradisionele interpretasie van die Markaanse eskatologie kom in kort op die volgende neer: Jesus het 'n koninkryk van God verkondig wat sal aanbreek wanneer $\mathrm{Hy}$, na sy dood, opstanding en verhoging as "Seun van die mens" (Bousset) sal terugkeer as "Seun van die mens" (vgl Dan 7:13) om die wêreld te oordeel (Mark 8:38; 13:26; 14:62; Weiss en Perrin). Hierdie wederkoms van Jesus - as die verhoogde "Seun van die mens" - sal kataklismies en apokalipties ${ }^{1}$ van aard wees, 'n skielike en onverwagse ingrype van God wat die geskiedenis van hierdie wêreld tot 'n einde sal bring en die bedeling van die koninkryk van God sal inlei. Markus het hierdie koms van die "Seun van die mens" (asook die gebeure wat hierdie koms sal

\footnotetext{
${ }^{1}$ Hierdie begrip is geyk deur Bretschneider (1804).
} 
voorafgaan) beskryf deur gebruik te maak van 'n bestaande Joodse "klein Apokalips" as bron, ${ }^{2}$ waarvan die verwerking in Markus 13 neerslag gevind het.

Hierdie kort beskrywing van die tradisionele verstaan van die Markaanse eskatologie impliseer onder andere die volgende: eskatologie word tydgewys as liniêr verstaan, Markus 13 is apokalipties in karakter, die begrip "Seun van die mens" word titulêr (as 'n Christologiese titel) geïnterpreteer, en die koninkryk van God word as 'n transendentale en toekomstige entiteit gesien.

In die onderhawige bydrae word die eskatologie van Markus ondersoek met as uitgangspunt die narratiewe struktuur van die evangelie as vertelling. Aandag word gegee aan die narratiewe struktuur van Markus, die Markusverteller se gebruik van tyd, die narratiewe funksie wat Markus $13^{3}$ in die Markusvertelling vervul, asook die narratiewe funksie van die seun van die mens-uitsprake in Markus. ${ }^{4}$ Met hierdie as fokus sal die volgende tese beredenaar word: In Markus funksioneer die Seun van die mens-uitsprake sonder uitsondering - op 'n nie-titulêre wyse met as funksie die beskrywing van Jesus se vervanging van die eksklusiewe tempel (huishouding) met 'n nuwe inklusiewe huishouding (koninkryk). Markus 13, vervolgens, word deur die verteller as apokaliptiese genre ingespan om 'n bepaalde verstaan van die eskatologiese gebeure in Jesus te legitimeer, te wete dat die koms van die Seun van die mens in die Evangelie verstaan moet word as God se vindikasie van Jesus na sy dood (opstanding). Ten slotte sal aangetoon word dat Markus se begrip "koninkryk van God" en sy verstaan van die eskatologie so nou met mekaar verweef is dat in Markus die koninkryk en eskatologie as uitruilbare terme beskou kan word - volgens die Markusverteller is die eskatologiese gebeure die koninkryk. Ten slotte word 'n moontlike

\footnotetext{
${ }^{2}$ Die moontlikheid dat Markus 13 die verwerking van 'n bestaande pre-Markaanse tradisie is, is eerste deur Colani gesuggereer.

${ }^{3}$ Markusnavorsers konsentreer gewoonlik, wat Markus 13 betref, op die moontlike bron(ne) waarvan die skrywer gebruik gemaak het, die literêre wordingsproses van Markus 13, die moontlike buite-tekstuele referente waarna verwys word, asook die vraag of Markus 13 geskryf is vanuit 'n apokaliptiese perspektief. Daar is egter geen rede, volgens Vorster (1987:204), "why the interpretation of this chapter should be restricted to this limited perspective".

${ }^{4}$ Markus bevat veertien "Seun van die mens"-uitsprake. Volgens Bultmann $(1931,1948)$ en heel waarskynlik vroeër Jackson \& Lake (1920:368) kan hierdie "Seun van die mens"uitsprake in drie kategorieë ingedeel word: die wat verband hou met die aardse aktiwiteit van Jesus (Mark 2:10, 28), die wat verband hou met die lyding van Jesus (Mark 8:31; 9:9, 12, 31; 10:33, 45; 14:21a, 21b, 41) en die wat verwys na Jesus se wederkoms (Mark 8:38; 13:26; 14:62). Hieronder sal geargumenteer word dat hierdie kategorieë van Bultmann, wanneer Markus as vertelling gelees word, nie op Markus van toepassing gemaak kan word nie.
} 
sosiohistoriese situasie van die Markaanse gemeente gepostuleer waarin bogenoemde verstaan van eskatologie en koninkryk sin sou kon maak.

\section{ESKATOLOGIE EN SEUN VAN DIE MENS IN MARKUS}

\subsection{Eskatologie}

Meeste Nuwe-Testamentici verstaan onder die begrip "eskatologie" die (nabye) verwagting van die einde van hierdie wêreld, 'n gebeure wat iewers in die toekoms sal plaasvind (kyk bv Langkammer, Witherington, Taylor \& Keener, in Malina 2002:52). Verder word aanvaar dat hierdie verwagte "einde" op 'n kataklismiese wyse sal plaasvind, vandaar die bekende begrip "apokaliptiese eskatologie" wat dikwels gebruik word om ons moderne verstaan van die eskatologie uit te druk. Feitlik alle vorige interpretasies van Markus 13 kan hiervan as voorbeeld dien.

Onderliggend aan hierdie verstaan van eskatologie is die moderne Westerse verstaan van tyd as liniêr. Hierdie verstaan van tyd is dan ook die rede waarom die meeste geleerdes, wanneer daar oor die begrip eskatologie in die Nuwe Testament nagedink word, 'n "progressiewe uitbly van die nabye einde" in die dokumente van die Nuwe Testament bespeur ${ }^{5}$ (Balabanski 1997:2). Die moderne (Westerse) verstaan van die Nuwe-Testamentiese eskatologie fokus daarom ook, op enkele uitsonderings na, op die uitbly van die wederkoms van Jesus Christus en die veronderstelde teleurstelling wat

\footnotetext{
${ }^{5}$ Die Wirkungsgeschichte van hierdie verstaan van die eskatologie in die Nuwe Testament is welbekend, en kan in kort soos volg opgesom word (kyk Balabanski 1997:4-10): Weiss (1971) was van mening dat die koninkryk wat Jesus verwag het nie as praesenties en futuristies verstaan moet word nie, maar uitsluitlik as futuristies. Hierdie tese van Weiss, saam met die bydraes van Reimarus en Strauss (wat verband hou met die verhouding tussen die verkondigende en verkondigde Jesus), het nie alleen die historisiteit van Jesus bevraagteken nie, maar ook die Duitse teologie met 'n fundamentele vraag gekonfronteer: as Jesus se verstaan van die koninkryk uitsluitlik 'n futuristiese entiteit was wat op die laatste in die volgende generasie sou realiseer, hoe kon Jesus so verkeerd gewees het? Schweitzer (1954) se antwoord op Weiss was sy bekende "konsequente Eschatologie", gevolg deur die werke van Conzelmann (1959, 1960) en Grässer (1977) wat van opinie was dat die koninkryk wat Jesus verkondig het wel praesenties en futuristies was, en dat die uitbly van die paroesie 'n groot rol gespeel het in die aard en vorming van die vroeë kerk. Dodd (1936) op sy beurt, se antwoord op die implisiete vraag van Weiss was sy bekende gerealiseerde eskatologie: Jesus het die koninkryk as praesenties verstaan, en van simboliese en metaforiese taal (sy gelykenisse) gebruik gemaak om aan te toon dat die koninkryk reeds aangebreek het. Jesus se verwysing na die koninkryk in simboliese (apokalities-eskatologiese) taal is egter nie deur die vroeë kerk verstaan nie, en Jesus se "apokaliptiese" taal is gebruik om hulle eie verstaan van die eskatologie tot uitdrukking te bring. In laasgenoemde verband is die volgende opmerking van Bornkamm (1951) steeds ter sake: "[T]he New Testament documents do not reflect the bitter disappointment in expectation which one might have expected; the fact that the early church survived the non-occurrence of the parousia without a significant break en without relinquishing its eschatological hope ... [is] ... a puzzle which had not yet been fully solved".
} 
hierdie uitbly van die wederkoms van Jesus by die vroegste Christelike gemeenskappe gewek het. $^{6}$

Balabanski (1997:4-10) en Malina (2002a:50-53) is van oordeel dat hierdie verstaan van eskatologie 'n moderne konstruk is. ${ }^{7}$ Volgens Malina is die begrippe "eskatologie" en die "uitbly van die eskatologie" (asook die begrippe "apokalipties" en "heilsgeskiedenis") wat die meeste geleerdes gebruik om die temporele (liniêre) dimensie van die teologie van die Nuwe Testament te beskryf nie alleen moderne begrippe nie, maar ook onakkuraat en misleidend wanneer dit gebruik word om die dokumente in die Nuwe Testament, asook enige ander eerste-eeuse Mediterreense dokument, te probeer verstaan (Malina 2002a:50). Die rede hiervoor, aldus Malina, is dat die begrippe "eskatologie" en "eskatologies", soos dit deur moderne navorsers gebruik word , 'n temporele (liniêre) dimensie veronderstel. ${ }^{8}$ Hierteenoor het antropologiese en kruis-kulturele studies aangetoon dat persone in die eersteeeuse Mediterreense wêreld tyd nie as liniêr en toekomsgerig verstaan het nie, "but rather markedly present-orientated, with past second en future third". An event that was about to happen was forthcoming, a sort of expanded present rooted in a process launched in the present. If some "end" were

\footnotetext{
6 "In modern scholarship the delay of Christ's return en the presumed disappointment it engendered has been seen as a primary factor, and in some cases as the primary factor, in the development of Christian eschatology" (Balabanski 1997:4; beklemtoning in die oorspronklike). Volgens Balabanski vertoon die eskatologie in die Nuwe Testament 'n verskeidenheid wat neerkom op meer as bloot liniêre ontwikkeling: "[T]he historical contexts of the various communities seem to have led to a greater variation in Naherwartung than our modern theories would suggest. ... Eschatological development in the New Testament is therefore not primarily grounded in a 'history of ideas', but rather grounded in historical particularities" (Balabanski 1997:2-3).

${ }^{7}$ Dit is belangrik om daarop te let dat Balabanski en Malina die oortuiging dat ons verstaan van die eskatologie ' $n$ moderne konstruk is, op verskillende argumente baseer. Balabanski aanvaar wel dat die vroeë Christelike beweging gekarakteriseer kan word deur'n nabye paroesieverwagting, maar oordeel tog dat "eskatologie" by die meeste navorsers as 'n moderne konstruk figureer aangesien die ontwikkeling van die eskatologie in die Nuwe Testament verstaan word deur middel van wat sy 'n "blanket theory" (die uitbly van die paroesie) noem (Balabanski 1997:3). In 'n ondersoek van Matteus 24:1-13, Markus 13, Matteus 24 en Didaché 16 (met die werk van Aune [1975] en Bauckham [1980] as vertrekpunt) kom Balabanski tot die gevolgtrekking dat die wyd aanvaarde model van deeskatologisering (die progressiewe taan van 'n eskatologiese verwagting soos die tyd verloop) nie in hierdie dokumente aanduibaar is nie. Matteus, byvoorbeeld, het 'n meer imminente eskatologiese verwagting as Markus (wat vroeër as Matteus geskryf is). Haar gevolgtrekking is dat die eskatologiese verwagting wat in die onderskeie dokumente van die Nuwe Testament bespeur kan word nie gesien moet word as die gevolg tydsverloop en daarom de-eskatologisering nie, maar eerder gesoek moet word in die spesifieke historiese omstandighede waarin elke spesifieke gemeenskap hulle bevind het (bv sporadiese vervolging wat tot 'n periodieke intensivering van die verwagting van ' $n$ imminente paroesie gelei het, die dood van lede van 'n bepaalde geloofsgemeenskap, en interne of eksterne spanninge wat bepaalde geloofsgemeenskappe ervaar het). Malina se beoordeling van die begrip "eskatologie" as 'n moderne konstruk baseer hy op die oortuiging dat die betekenis van taal deur die sosiale sisteem wat die betrokke taal gebruik bepaal word, en in die geval van "eskatologie", die sosiale waarde van tyd (Malina 2002a:51).
}

\footnotetext{
${ }^{8}$ Volgens Malina (2002a:50-51) is die oorsprong van hierdie verstaan van "eskatologie" terug te vind in die agtiende- en negentiende-eeuse Noord Europese (Duitse) ideologie en behoefte aan kategorisering. Die begrip "heilsgeskiedenis" is die produk van die agtiende-eeu, en die begrippe "eskatologie", "eskatologiese vertraging" en "die uitbly van die paroesie" produkte van die negentiende eeu. Eskatologie is dus ' $n$ Noord Europese skepping wat gebruik word om die sogenaamde temporele dimensies van Nuwe-Testamentiese teologie te beskryf. Hierdie beskouing van die eskatologie van die Nuwe Testament het, volgens Malina, die sogenaamde "Received View" geword, en enige interpretasie van die eskatologie in die Nuwe Testament wat ooreenstem met of voortbou op hierdie "Received View", daarom 'n interpretasie is waarvan kennis geneem behoort te word (en natuurlik vice versa).
} 
coming soon that is only because of what was under way in the present" (Malina 2002a:51; kyk ook Malina 1989:1-31). ${ }^{9}$ Hierby kan gevoeg word dat die dokumente van die Nuwe Testament die produk van hoë-konteks gemeenskappe ("high-context society") is (kyk Malina 2002b:5). Persone in hoë-konteks gemeenskappe se sosialisering is van so 'n aard dat almal op dieselfde wyse verstaan en optree - 'n bepaalde verstaan van sake en optrede in sekere situasies wat so vanselfsprekend is dat dit nooit uitgespel word of hoef uitgespel te word nie. Om hierdie rede word die eerste-eeuse Mediterreense persoon se verstaan van tyd as praesenties-georiënteerd (en nie futuristies-georiënteerd nie) in hulle dokumente "gemistifiseer"10 (Malina $1991: 20)$. Malina oordeel daarom dat 'n verstaan van die "eskatologie" van die Nuwe Testament, as sou dit verwys na iets wat in die toekoms gaan gebeur (ook genoem die "uitbly van die paroesoe"), in wese op 'n etnosentristiese of anakronistiese lees van die dokumente van die Nuwe Testament neerkom.

\subsection{Die "Seun van die mens" in die Markusevangelie}

Interpretasies van die Seun van die mens-uitsprake in Markus loop in twee duidelike rigtings uiteen. Sommige Nuwe-Testamentici is van oortuiging dat hierdie uitsprake (veral die sogenaamde eskatologiese Seun van die mensuitsprake; nl Mark 8:38; 13:26 en 14:62) van Daniël 7:13 (as verwysend na 'n individuele messiaanse figuur) as interteks afhanklik is, titulêr verstaan moet word, en na die wederkoms (paroesie) van Jesus verwys (vgl bv Montgomery 1927:317-320; Casey 1979; 1987:27-28; 1991:17-43; 1994:87-118;

Bauckham 1980:3-36; 1983:97; Marshall 1992:195-198; Ehrman 1999; Burkett 1999; Carrol 2000:11; Schröter 2001; Hurtado 2005:293; Adams 2005:39-61; ${ }^{11}$ Shepherd 2006:111).

\footnotetext{
${ }^{9}$ Herzog (2000) en Bolt (1995:14-15) is ook van oortuiging dat die tydsoriëntering van die Bybelse dokumente nie toekomsgerig is nie. Volgens Herzog was die profete van Israel (en daarom ook Jesus) "not so much driven by a vision of the future as by a confidence in the past, the past that antecedently shaped their present en could continue to influence its forthcoming course" (Herzog 2000:58 vgl Malina 2002a:51). Bolt (1995:14-15) is van dieselfde oortuiging: "[T]he future did not have a two-stage structure. The eschatology that Jesus en Israel shared was that of the Old Testament which appears to have looked forward to the one great event at the end of history, namely the arrival of the kingdom of God".

10 "High context societies produce sketchy en impressionistic documents, leaving much to the readers' or hearers' imagination and common knowledge. Since people living in these societies believe that few things have to be spelled out, few things in fact are spelled out .... $[T]$ he typical communication problem in high context societies is not giving people enough information, thus 'mystifying' them" (Malina 2001; my beklemtoning).

${ }^{11}$ Adams (2005:43-48), as voorbeeld, is van die oortuiging dat Markus 8:38; 13:26 en 14:62 se gebruikmaking van Daniël 7:13 laasgenoemde op so 'n wyse met ander Ou-Testamentiese tekste (bv Sag 14:5; Jes 59:19; 66:18; Hab 3:3) en met sekere motiewe van God se koms na die aarde in 1 Henog 37-71 en 4 Esra 13 koppel, dat hierdie seun van die mens-uitsprake nie anders geïnterpreteer kan word as sou dit verwys na Jesus se paroesie as 'n toekomstige gebeure nie (kyk ook Schröter 2001:61).
} 


\section{Eskatologie en koninkryk in die Markusevangelie}

Ander Nuwe-Testamentici weer is van die oortuiging dat die eskatologiese Seun van die mens-uitsprake in Markus nie met Daniël 7:13 as interteks verbind moet word nie, en as nie-titulêr verstaan moet word. Die standpunt van Vermes (1967:316-317) is in hierdie verband seker die bekendste: ${ }^{12}$ geen verband tussen die Seun van die mens-uitsprake en Daniël 7:13 kan veronderstel word nie, aangesien die begrip "Seun van die mens" se antesedent in die Aramese gebruik van bar nasha terug te vind is. Vermes konkludeer, op grond van sy bestudering van Aramese bronne, dat die begrip "seun van die mens" bloot as sinoniem van die woord "man", en substituut vir die onbepaalde voornaamwoord "iemand", gesien moet word. Die begrip "seun van die mens" moet daarom, afhangende van die konteks waarin dit voorkom, met "iemand", "enigeen" of "ek" vertaal word. Om hierdie rede is dit daarom onwaarskynlik dat die begrip op 'n titulêre wyse verstaan kan word (kyk ook Perrin 1966:28; Cullmann 1971:155-164; Svendlund 1974:21-22; Bietenhard 1982:272; Kümmel 1984:160; Lindars 1983:194; Crossan 1991:238-255; Collins 1996:139-158; Van Aarde 2002:1625-1653; 2004:426; Loba-Mkole 2003:838-839). ${ }^{13}$

Daar is verder ook Markusnavorsers wat van die oortuiging is dat die Markaanse Jesus se Seun van die mens-uitsprake nie verwys na die paroesie nie, maar na Jesus se vindikasie deur God na sy dood (opstanding). France (1971; 1990; 2002:341-343, 500-503, 530-537) en Wright (1996:360-367, $510-519 ; 2001: 111-112,183-184)$, alhoewel albei van oortuiging is dat Daniël 7:9-14 as antesedent van die Seun van die mens-uitsprake in Markus 8:38, 13:26 en 14:62 gesien moet word, is verteenwoordigers van hierdie standpunt. France se oortuiging dat die eskatologiese Seun van die mensuitsprake na die vindikasie van Jesus na sy opstanding verwys, en nie die wederkoms nie, baseer hy op die volgende interpretasie van Markus 8:38, 13:26 en 14:62: Die verwysing in Markus 8:38 na die engele wat Jesus by sy wederkoms sal vergesel, en die heerlikheid wat Jesus sal beklee, verbind Markus 8:38 respektiewelik met Daniël 7:9-10 en 7:14. In Markus 8:38 kyk Jesus vooruit na sy heerlikheid en mag wat Hy sal ontvang na sy opstanding. Markus13:26, soos in die geval van Markus 8:38, verwys ook na Daniël se

\footnotetext{
${ }^{12}$ Lietzmann was die eerste Nuwe-Testamentikus wat van oordeel was dat al die Seun van die mens-uitsprake bloot na "mensheid" verwys, alhoewel hy later van opinie verander het (kyk Van Aarde 2004:425).

${ }^{13}$ Vir 'n beskrywing van die linguistiese vorme wat vir die uitdrukking seun van die mens in antieke, middel en Galilese Aramees gebruik is, asook die status daarvan (absoluut, onbepaald of emfaties), kyk Loba-Mkole (2003:838-839). Hy sluit genoemde beskrywing opsommend soos volg af: "Notwithstanding the different forms en states, the central meaning of the Aramaic expression seems to have remained the same, namely a male human person. In other words, in Aramaic the expression 'son of man' refers to a human being in generic, indefinite en circumlocutional sense" (Loba-Mkole 2003:839).
} 
beeld van troonbestyging, dus ook 'n verwysing na die heerlikheid wat Jesus sal beklee na sy opstanding. Dieselfde geld vir Markus14:62. Alhoewel

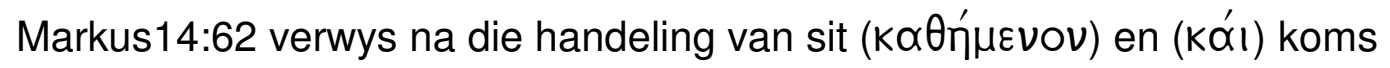

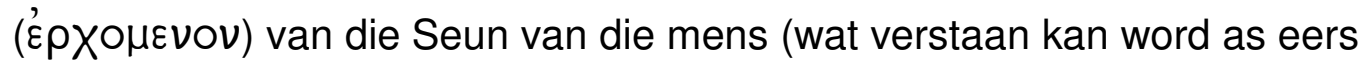
verhoging/opstanding en dan wederkoms), is France van oordeel dat Markus hier met twee metafore werk wat dieselfde betekenis het, te wete Jesus se vindikasie deur God na sy opstanding. So verstaan, verwys Markus 14:62 (soos Mark 8:38 en 13:26) dus na Jesus se opstanding as vindikasie van God (kyk France 1971:139; 2002:343, 533, 612). Ook belangrik, volgens France, is om raak te sien dat al drie hierdie verwysings na Daniël 7:13 'n eksplisiete tydsbeperking bevat, te wete dat dit sigbaar sal wees in die tyd van die huidige generasie (France 1990:82).

Wright se analise van bogenoemde drie eskatologiese Seun van die mens-uitsprake van Jesus kom ooreen met die van France. Hy druk sy verstaan van Markus 8:38, 13:26 en 14:62 soos volg uit: "[These sayings] concern the vindication of his entire programme and mission God will bring to pass, after his own death, with the destruction of the Temple that has come to symbolize all that his gospel opposes" (Wright 2001:184). Alhoewel Wright meer klem as France plaas op die verwoesting van die tempel as deel van Jesus se vindikasie deur God, kom sy verstaan van Markus 8:38, 13:26 en 14:62 in wese met die van France ooreen. Soos in die geval van France, beklemtoon Wright dat hierdie interpretasie van Markus 8:38, 13:26 en 14:62 alleen sin van Markus 8:38, 9:1, 13:26 en 13:30 kan maak, te wete dat hierdie gebeure (die koms van Jesus as opstanding en vindikasie) nog in die leeftyd van die hoorders van die Evangelie (huidige geslag) sal plaasvind.

\section{DIE NARRATIEWE STRUKTUUR VAN MARKUS}

\subsection{Die oorkoepelende raamwerk van Markus se struktuur: Galilea (nuwe huishouding) en Jerusalem (tempel)}

Die struktuur van Markus, die struktuur van kleiner eenhede in die Evangelie (bv Mark 2:1-3:6; ${ }^{14}$ Mark 4:1-8:26; ${ }^{15}$ Mark 8:22-10:52), ${ }^{16}$ asook die tipiese

\footnotetext{
${ }^{14}$ Kyk byvoorbeeld Dewey (1980).

${ }^{15}$ Kyk byvoorbeeld Petersen (1980:185-217), Fowler (1981) en Duling (1994:302).

${ }^{16}$ Kyk byvoorbeeld Best (1970; 1983) en Van lersel (1988).
} 


\section{Eskatologie en koninkryk in die Markusevangelie}

struktuurvorme wat Markus gebruik om sy teks te struktureer, ${ }^{17}$ was en is die fokus van 'n magdom bydraes ten opsigte van die verstaan van die Evangelie (kyk bv Vorster 1983:122-124; Achtemeier 1986:30-40; Duling 1994:303-305). Alhoewel Markusnavorsers, wat die oorkoepelende struktuur van Markus betref, hier en daar ten opsigte van kleinere detail verskil, is daar konsensus wat veral drie aspekte van Markus se narratiewe struktuur en tegniek betref, en wat in die onderhawige studie van belang is om Markus se eskatologie en gebruik van die begrip koninkryk te verstaan: Eerstens toon Markus se struktuur 'n beweging vanaf Galilea na Jerusalem. ${ }^{18}$ In die tweede plek bevat Markus se narratief drie ineengevlegte storielyne (die van Jesus, sy dissipels en die godsdienstige leiers; kyk o a Tannehill 1980; 1983; Kingsbury 1989; Van Eck \& Van Aarde 1989) wat in die Markusvertelling op 'n baie spesifieke wyse ontwikkel word. Derdens is verskeie Markusnavorsers van mening dat Markus die geneigdheid toon om in die meeste van sy inleidende verse van perikope, sy opsommende gedeeltes, en oorgangsverse wat perikope aan mekaar verbind, bepaalde lokaliserings in te voeg wat simboliese (teologiese) betekenis in sy vertelling dra. Voorbeelde van sodanige lokalisering is die see van Galilea, Galilea, woestyn, graf, berg, die weg en Jerusalem (kyk veral Malbon 1982, 1986).

Laasgenoemde aspek hierbo genoem is veral van belang vir die verstaan van die eie-aard van die Markaanse eskatologie en die verteller se gebruik van die begrip koninkryk (asook die verband tussen hierdie twee

\footnotetext{
${ }^{17}$ Die struktuurvorme tipies aan Markus is die volgende: die verwysing na gebeure of persone en uitsprake van Jesus in 'n reeks van drie (broer, suster en moeder [Mark 3:35], Petrus, Johannes en Jakobus [Mark 5:37; 9:2; 14:33], priesters, skrifgeleerdes en familiehoofde [Mark 8:31; 11:27; 14:43; 15:1]), die dissipels raak drie keer aan die slaap ([Mark 14:32-42], drie lydensaankondigings [8:31; 9:31; 10:33-34], en Petrus wat Jesus drie keer verloën [Mark 14:66-72]); "toebroodjies" of "invoegings" (die vertelling oor die reiniging van die tempel [Mark 11:15-19] wat ingevoeg word tussen die vervloeking van die vyeboom en Jesus se verduideliking van die betekenis daarvan [Mark 11:12-14; 11:20-25], die vertelling oor die vrou wat aan bloedvloeiïng gely het [Mark 5:25-34] wat ingevoeg word in die grotere vertelling oor die genesing van Jaïrus se dogter [Mark 5:21-24 en 5:35-43]), die groot "toebroodjie" in die middel van die Markusvertelling ([Mark 8:22-10:52], en Jesus se drie lydensaankondigings [Mark 8:31; 9:31; 10:33-34] wat ingevoeg is tussen twee vertellinge oor blinde persone wat genees word [Mark 8:22-26; 10:46-52]); die herhalende patroon van openbare lering aan die skare en private uitleg aan die dissipels (Mark 4:1-12; 7:14-23; 9:14-29; 10:1-10; 13:1-8); en die aaneenskakeling van verskillende mikrovertellings deur middel van inleidings (Mark 1:113; 13:1-5a;14:1-12), opsommings (Mark 1:14-15; 3:7-12; 6:6b) en oorgangsgedeeltes (oorgangsverse; Mark 8:22-26;10:46-52).

${ }^{18}$ Die oorkoepelende struktuur in Markus ten opsigte van die vertelling se beweging vanaf Galilea na Jerusalem is soos volg: Jesus in Galilea (1:14-6:13), Jesus buite Galilee (6:148:26), Jesus op weg vanaf Sesarea-Filippi na to Jerusalem (8:27-10:52), en Jesus in Jerusalem (11:1-16:8).
} 
sake), en verdien daarom verdere aandag. ${ }^{19}$ Lohmeyer $(1936,1942)$ was die eerste Markus-navorser wat aandag op die belangrike teenstelling tussen Galilea en Jerusalem in die Evangelie gevestig het. Volgens Lohmeyer het die vroeë Christendom in Palestina twee sentra gehad, te wete Galilea en Jerusalem. In Galilea (as die nuwe "kommende Gotteshaus") het die klem op die evangelie en die eskatologie geval, terwyl Jerusalem (as die tradisionele "Gottestadt") gefokus het op die kultus en 'n messiaanse nasionalistiese hoop. Jesus het met sy openbare optrede in Galilea (bv die vergewing van sondes, die eet saam met sondaars en ongehoorsaamheid ten opsigte van die Sabbatswette en vastye) konflik veroorsaak wat op Jerusalemse kultus gemik was. Met hierdie optrede, aldus Lohmeyer, het Jesus 'n "neue Heiligkeit und neues Heil" daargestel en die tradisionele "Gottestadt" met die nuwe "kommenden Gotteshaus" vervang. Galilea was ook die plek waar die vervulde eskatologiese koninkryk, waarna Jesus in onder andere in Markus 14:28 en 6:7 verwys het, sou aanbreek.

Bogenoemde insigte is verder gevoer deur onder andere Lightfoot (1938), Marxsen (1959) en Kelber (1974). Lightfoot, deur te konsentreer op die einde van die Markusvertelling, stem met Lohmeyer saam dat die teenstelling tussen Galilea en Jerusalem neerkom op 'n verskil in verstaan van eskatologie: omdat Jerusalem Jesus verwerp het, was Galilea die sfeer van die Goddelike openbaring. Marxsen, in sy (die eerste) Redaktionsgeschichtliche analise van Markus, het bogenoemde insigte van Lohmeyer en Lightfoot verder gevoer. Marxsen was van oordeel dat in die tyd waarin Markus geskryf is, eskatologiese verwagtings in Galilea so hoog was, dat Markus, deur middel van sy redaksionele aktiwiteit, Galilea die plek van Jesus se huidige en toekomstige optrede gemaak het. Die wyse waarop die Markusredaktor hierdie klemtoon bewerkstellig het, was om in die meeste van sy redaksionele opmerkings en byvoegings die pleknaam (topos) Galilea in te voeg (kyk bv Mark 1:7; 3:7-8). Op hierdie wyse het Markus 'n evangelie geskep waarin Galilea die plek is "where Jesus worked ... is now working, and will work at his Parousia" (Marxsen 1959:94). Kelber het, deur te konsentreer op die "koninkryk-passasies" in Markus (Mark 1:15; 3:31-35; 4:10-34; 8:349:1), ook tot dieselfde slotsom gekom: die teenstelling tussen Galilea en Jerusalem in Markus is een van 'n verskil in verstaan van eskatologie. Vir Markus, aldus Kelber, was Galilea - en nie Jerusalem nie - die plek van die koninkryk en die paroesie. Die tyd waarop die paroesie sou plaasvind was

\footnotetext{
${ }^{19}$ Vir die opsomming wat volg oor die teëstelling tussen Galilea en Jerusalem in Markus is grootliks gebruik gemaak van die bydrae van Malbon (1982:242-255). Vir 'n meer volledige opsomming van Malbon, en andere se standpunte in hierdie verband, kyk Van Eck (1995:1216).
} 


\section{Eskatologie en koninkryk in die Markusevangelie}

egter nie gedurende Jesus se generasie nie, maar die tyd waarin die skrywer gelewe het.

Die histories-kritiese ondersoek van Galilea en Jerusalem in Markus het dus die volgende opgelewer: die teëstelling tussen Galilea en Jerusalem in Markus is in wese ' $n$ verskil in verstaan van eskatologie en koninkryk. Die plek van die koninkryk is Galilea, so ook die plek waar die wederkoms sal plaasvind, 'n gebeure wat homself in die tyd van die skrywer sal afspeel.

Bogenoemde insigte vanuit die historiese kritiek het as stimulus gedien vir verskeie literêr-kritiese ondersoeke na die struktuur van Markus. In een van die mees volledigste literêr-kritiese ondersoeke van die struktuur van Markus oordeel Van lersel (1989) dat Galilea en Jerusalem in Markus wel in opposisie teenoor mekaar geplaas word, maar dat hierdie opposisie nie die enigste - en belangrikste - teenstelling in Markus is nie. In Markus word twee teenstellings aangetref, Galilea teenoor Jerusalem, en woestyn teenoor graf. Hierdie twee opposisies word deur Markus funksioneel aangewend om op die eintlike belangeruimte in Markus te fokus, te wete "die weg" van Jesus vanaf Galilea na Jerusalem (Mark 8:22-10:52). Die weg van Jesus is 'n weg van woestyn na graf (twee ruimtes waarin lewe en dood belangrike funksies vervul), en 'n weg vanaf Galilea na Jerusalem ('n weg van konflik tussen die aktiwiteit van Jesus in Galilea en die opponering daarvan deur die godsdienstige leiers in Jerusalem). So verstaan, is die weg van Jesus 'n pad van lyding. Rhoads \& Michie (1982:63-72), in 'n narratologiese ondersoek van die Markusvertelling, kom tot dieselfde gevolgtrekking: in Markus staan die aktiwiteit van Jesus in Galilea ("ruling for God") in konflik met die aktiwiteit van die godsdienstige leiers in Jerusalem ("ruling for themselves"), met die weg van Jesus vanaf Galilea na Jerusalem as "funneling effect" vir Markus se plot.

Die insigte van Van lersel en Rhoads \& Michie is deur Van Eck (1995) verder geneem deur op ruimte (topos) in Markus te fokus vanuit 'n sosiaalwetenskaplike en narratologiese perspektief. Sy gevolgtrekkings kom in kort op die volgende neer: die teëstelling in Markus tussen Galilea en Jerusalem kan meer spesifiek beskryf word as die teëstelling tussen die inklusiewe huishouding deur Jesus geskep in Galilea en eksklusiewe huishouding (tempel) in Jerusalem. In Markus funksioneer die begrip koninkryk as 'n simbool vir die plek waar God se redding beskikbaar is. Hierdie plek is die inklusiewe huishouding (in Galilea) van Jesus. So verstaan, is koninkryk en inklusiewe huishouding (Galilea) twee uitruilbare terme in Markus se vertelling oor Jesus: die koninkryk is die huishouding en die huishouding is koninkryk. Hierdie nuwe huishouding van God is deur Jesus op Galilese bodem gevestig veral deur sy eksorsismes en ander genesings (waardeur onrein persone ["sondaars"] herstel is tot hulle normale funksies in die konteks van huis en familiale verhoudinge). Jesus se eksorsismes en genesings dien verder om aan te toon dat Jesus, en nie die godsdienstige 
leiers in Jerusalem nie, die een is wat die gesag het om mense deel van die nuwe inklusiewe huishouding van God (die koninkryk) te maak. Jesus is daarom ook die een wat gesag oor die tempel (en die res van God se wêreld) het. Die wyse waarop Jesus die karaktertrekke en interne verhoudinge van die nuwe huishouding (as inklusief, egalitêr, nie-seksisties, met God as onmiddelike teenwoordig) verstaan het, was duidelik in die wyse waarop en saam met wie Jesus geëet het. Die nuwe huishouding se verhouding na buite het duidelik geword in Jesus se interpretasie van die reinheidsmaatreëls soos voorgestaan deur die eksklusiewe tempel in Jerusalem. Jesus se negatiewe houding teenoor die eksklusiewe reinheidskodes en reinheidsmaatreëls van die tempel, gekombineer met sy vergewing van sondes op Galilese bodem, het die tempel as obsoleet verklaar. Verstaan vanuit hierdie perspektief was Jesus se tempelaksie in Jerusalem dus nie iets nuuts of onverwags nie: soos die godsdienstige leiers (veral die Fariseërs) die tempel en tempelmaatreëls ook in Galilea wou laat neerslag vind (repliseer) in elke huishouding (bed en tafel), so het Jesus deur sy tempelaksie die nuwe huishouding van Galilea in die tempel in Jerusalem gerepliseer (as 'n huis van gebed vir alle nasies).

\subsection{Narratiewe tyd (plotted time) en storietyd (story time) in Markus}

Die literêre begrip "storietyd" verwys na die wat van 'n narratief (oa tyd [die kronologie van gebeure], karakters en ruimte), en "narratiewe tyd" na die hoe van 'n narratief, dit wil sê, die wyse waarop die storie vertel word (bv hoe die kronologiese gebeure van die storie [story time] in die vertelling geplot word [plotted time]). Prolepsis (prospeksie) en analepsis (retrospeksie) is in hierdie verband belangrike aspekte wanneer 'n verteller se gebruik van tyd ondersoek word, veral om storietyd en narratiewe tyd van mekaar te onderskei (kyk bv Chatman 1978:17-41).

In wat volg sal die Markusverteller se gebruik van narratiewe tyd in terme van die storielyne van Jesus, die dissipels en die godsdienstige leiers eerste onder die loep kom, met inagneming van die makrostruktuur van Markus as vertelling soos bo beskryf is. Daarna sal aandag gegee word aan Markus se gebruik van storietyd, met as fokus die wyse waarop Markus storietyd op 'n proleptiese wyse in sy narratief geplot het. Die Seun van die mens-uitsprake in Markus, Markus 13, en Markus 14:28 en 16:7 sal hier spesifieke aandag ontvang.

\subsubsection{Narratiewe tyd in die Markusvertelling}

\subsubsection{Die narratiewe storielyn van Jesus: Die herstel van God se huishouding (koninkryk) as vervanging van die tempel}

Jesus se herstel van die huishouding van God begin in Markus 1:15 wanneer Jesus verklaar dat die tyd van die koninkryk van God aangebreek het. Die 


\section{Eskatologie en koninkryk in die Markusevangelie}

koninkryk (as metafoor vir die huishouding van God) is egter nog net "naby", nog nie 'n realiteit nie, aangesien Jesus dit nog moet laat realiseer in wat volg in die vertelling. $\mathrm{Na}$ hierdie aankondiging van Jesus begin $\mathrm{Hy}$ dadelik met die realisering van die beloofde koninkryk (nuwe huishouding) deur sy eerste vier dissiples in Galilea te roep (Mark 1:16-20). Hierdie roeping word onmiddellik gevolg deur drie aktiwiteite van Jesus wat sy herstel van God se huishouding in die res van die vertelling kenmerk: lering (Mark 1:21), eksorsismes (Mark 1:23-26) en genesings (Mark 1:29-31). Hierdie eerste lering, eksorsisme en genesing het as resultaat vier sake wat as herhalende temas in die res van die Galilea-gedeelte (Mark 1:15-8:21) van die vertelling funksioneer: Jesus tree op met gesag (Mark 1:22, 27), wat Hy doen word ervaar as iets nuut (Mark 1:27), die persoon wat genees word (Simon se skoonmoeder) gaan dadelik oor tot diens in die (nuwe) huishouding (Mark 1:31), en Jesus vervang die tempel met die nuwe huishouding (Mark 1:22).

In die res van die Galilea-gedeelte van die vertelling (Mark 1:32-8:21) sentreer Jesus se vervanging van die tempel met sy nuwe huishouding dan ook rondom hierdie selfde vier aktiwiteite: Hy roep Levi, 'n tollenaar ("sondaar"; Mark 2:14), leer (Mark 1:38-39; 2:2, 17, 18-22; 4:2-32; 6:2; 6), genees (Mark 1:32-33, 40-43; 2:3-11; 3:11; 5:22-42; 6:53-56; 7:31-36), en voer eksorsismes uit (Mark 1:32-33, 39; 3:12; 5:1-18; 7:34-30). Soos in die geval van Markus 1:16-31, word Jesus se lering, genesings en eksorsismes ervaar as iets nuut (Mark 2:12, 21-22), en Jesus tree op met gesag (Mark $1: 40 ; 4: 41 ; 5: 20 ; 6: 2 ; 7: 37)$. Hierdie gesag word beklemtoon deur 'n groot skare (skares) wat Jesus volg (Mark 1:37, 45; 2:1; 3:7-9, 20; 4:1, 34; 5:21), 'n verdere beklemtoning van dit waarmee Jesus besig is: die daarstel van ' $n$ nuwe huishouding van God (koninkryk).

Waar Jesus se vervanging van die tempel met sy nuwe huishouding in Markus 1:22 alleen implisiet afleibaar is, word dit in Markus 1:32-8:21 op 'n toenemende wyse meer eksplisiet sigbaar: In Markus 1:43-44 genees Jesus 'n melaatse man en stuur hom na die tempelpriesters om aan hulle te toon dat Jesus ook kan genees (Mark 1:44). In Markus 2:5 en 2:15-16 is Jesus se vervanging van die tempel met die nuwe huishouding selfs meer eksplisiet: deur sondes te vergewe en saam met tollenaars en sondaars te eet verklaar Jesus in wese die tempel en tempelmaatreëls as obsoleet. In Markus 2:18-22 gaan Jesus nog verder deur uit te spel wat $\mathrm{Hy}$ besig is om te doen: dit wat oud is, word met die nuwe vervang. Kort hierna loop die tempel se verstaan van die Sabbat deur (Mark 2:23-27), en in Markus 3:1-7 gaan Jesus so ver om 'n "dubbele oortreding" te begaan deur 'n man met 'n gebreklike hand op die Sabbat te genees. Aan die einde van hierdie Galilea-gedeelte van die vertelling kom die reinheidsmaatreëls van die tempel weer in die spervuur wanneer Jesus alle voedsel rein verklaar (Mark 7:19). Die kontoere van die nuwe huishouding is dus duidelik: dit is inklusief in karakter, en hulle wat 
bereid is om te "bekeer" (Mark 1:15) en die "wil van God" te doen (Mark 3:34), het broers en susters van mekaar en deel van die nuwe huishouding geword.

Wanneer Jesus se optrede in Markus 1:32-8:21 met die van Markus 1:16-31 vergelyk word, is daar net twee verskille: Jesus doen wonderwerke (Mark 4:35-40; 6:35-44, 45-52, 8:1-10) wat aantoon dat Hy ook gesag oor die natuur het, en genees ook nie-Jode (Mark 7:24-30, 31-37). Die reaksie op hierdie wonders en genesings is egter dieselfde as in Markus 1:16-31 (kyk veral Mark 4:41; 7:37). Dus, met die uitsondering van Markus 6:3-6, word Jesus se daarstel van die nuwe huishouding in Galilea as vervanging van die tempel in Jerusalem as suksesvol beskryf. In kort: In Galilea "wen" Jesus.

Hierna begin Jesus se reis na Jerusalem (Mark 8:22-10:52). Terwyl Jesus op weg van Galilea na Jerusalem is, leer Hy sy dissipels wat die inhoud van God se nuwe koninkryk is: deelwees van hierdie nuwe huishouding beteken selfverloëning, die bereidheid om jou kruis te dra en selfs jou lewe te verloor, nie skaam te wees om deel van die nuwe huishouding te wees nie (Mark 8:34-36), en om eerste en die belangrikste in die koninkryk te wees beteken om laaste en almal se dienskneg te wees (Mark 9:35; 10:44). Bo alles moet hulle, wat deel van die koninkryk wil word, selfs bereid wees om hulle familie te versaak (Mark 10:24, 29-30).

In die Jerusalem-gedeelte van die vertelling (Mark 11:1-16:8) kom Jesus se suksesverhaal egter tot 'n einde. Sukses verander in "mislukking". Aanvanklik is die skare (wat Jesus gevolg het op sy weg vanaf Galilea na Jerusalem; kyk Mark 9:15; 10:1, 13, 32, 46) positief teenoor Jesus wanneer Hy Jerusalem binnegaan (Mark 11:8-10). Die skare bly selfs positief teenoor Jesus nadat Hy op 'n metaforiese wyse na die einde van die tempel verwys (Mark 11:12-14, 20-25), die tempel se eksklusiwiteit kritiseer (Mark 11:17), en 'n gelykenis vertel waarin daar gesinspeel word dat die tempel van die godsdienstige leiers weggeneem sal word en aan ander gegee sal word - 'n eksplisiete verklaring dat die nuwe inklusiewe huishouding van God, wat sy ontstaan in Galilea gehad het, die eksklusiewe tempel en tempelsisteem vervang en tot 'n einde gebring het. Na Jesus se gevangeneming (Mark 14:43-39) en sy verhoor voor die hoëpriester, priesters, familiehoofde en skrifgeleerdes (Mark 15:53-65), help die skare in 'n sekere sin van die woord egter vir Pilatus en die godsdienstige leiers om van Jesus ontslae te raak (Mark 15:6-14). Jesus word daarna gekruisig (Mark 15:21-32), waarna Hy sterf (Mark 15:33-38). In kort: In Jerusalem "verloor" Jesus.

\subsubsection{Die narratiewe storielyn van die dissipels: Van sukses na mislukking}

Die dissipels se vermoë om te verstaan wie Jesus is en deel van die nuwe huishouding te wees, blyk in terme van die narratiewe tyd van die vertelling, 'n mislukking te wees. Aanvanklik word die dissipels baie positief geteken: 


\section{Eskatologie en koninkryk in die Markusevangelie}

wanneer Jesus hulle roep volg hulle Hom onmiddellik (Mark 1:16-20) en reageer sonder voorbehoud positief wanneer Jesus hulle aanstel (Mark 3:1319) en uitstuur (Mark 6:7) om, soos Hy, mense op te roep tot bekering, te leer te genees, en eksorsismes uit te voer (Mark 6:12) - 'n opdrag wat hulle suksesvol uitvoer (Mark 6:30). 'n Negatiewe prentjie van die dissipels kom egter na vore in die drie bootverhale (Mark 4:35-41; 6:45-52, 8:14-21) in die Galilea-gedeelte van die vertelling: hulle het geen geloof nie, is verlore sonder Jesus, en verstaan nie wat Jesus se vermeerdering van die brood en vis beteken nie ( $\mathrm{nl}$ dat die nuwe huishouding inklusief is en 'n lewe van oorvloed impliseer). Ook wanneer Jesus aan hulle die geleentheid gee om die skare te voed, is die dissipels nie in staat om dit te doen nie.

In die middelgedeelte van die vertelling (Jesus op weg; Mark 8:2210:52) leer Jesus daarom sy dissipels wat dit beteken om deel van die nuwe huishouding te wees. Wanneer Petrus (as primus inter pares van die dissipels) bely dat Jesus die Christus is (Mark 8:29), blyk dit dat hy verstaan wie Jesus is. Wanneer Jesus egter vir die eerste keer aan hulle meedeel dat deelwees van die nuwe huishouding lyding impliseer, selfs dood (kyk Mark 8:31), word dit duidelik dat hulle nie verstaan wat die koninkryk is, wie Jesus is, en waarvoor Hy gekom het nie (Mark 8:32-33). Om hierdie misverstaan van die dissipels te probeer oorkom, leer Jesus hulle dan weer (Mark 8:349:1). Hierdie patroon van aankondiging - misverstaan - lering speel homself hierna nog twee keer in hierdie gedeelte van die vertelling af. Telkens wanneer Jesus aankondig dat deelwees van die nuwe huishouding lyding impliseer (Mark 9:31; 10:33-34), reageer die dissipels op 'n wyse wat duidelik toon dat hulle nie verstaan wat Jesus sê of bedoel nie (Mark 9:32, 34; 10:3537 ), en moet Jesus hulle weer leer wat dit beteken om deel van die nuwe huishouding te wees (Mark 9:33-37; 10:42-45).

In die Jerusalem-gedeelte van die vertelling bereik die dreigende konflik tussen Jesus en sy dissipels 'n hoogtepunt. Net voordat Jesus gevange geneem word raak hulle drie keer aan die slaap in plaas daarvan om te bid en te waak (Mark 14:32-42), en wanneer Jesus gearresteer word hardloop al die dissipels (behalwe Petrus) weg (Mark 14:50). Later versaak Petrus egter ook vir Jesus (Mark 14:66-73), en wanneer Jesus gekruisig word sterf Hy alleen, sonder sy dissipels. In kort: die dissipels "misluk".

\subsubsection{Die narratiewe storielyn van die godsdienstige leiers: Toenemende konflik en uiteindelik "sukses"}

Dit wil blyk of, op die vlak van narratiewe tyd van die vertelling, slegs die storielyn van die godsdienstige leiers in 'n sukses eindig. Die eerste verwysing na die skrifgeleerdes (heel waarskynlik deel van die Farisese-groep; kyk Mark $2: 16)$ vind op 'n indirekte wyse plaas wanneer die skare verstom is dat Jesus hulle met soveel gesag leer, anders as die lering van die skrifgeleerdes (Mark 
1:22). Dieselfde geld vir die volgende verwysing na die skrifgeleerdes (Mark 2:6) nadat Jesus 'n verlamde man se sonde vergewe (Mark 2:5). Ook die eerste verwysing na die tempelpriesters vind op 'n indirekte wyse plaas wanneer Jesus, nadat Hy 'n melaatse man genees het, die man na die tempel stuur om homself aan die priester(s) te gaan wys (Mark 1:40-42). Dit is verder duidelik dat die skrifgeleerdes en priesters in die vertelling funksioneer slegs wanneer Jesus se optrede (die daarstel van die nuwe huishouding) bots met die belange van die "ou huishouding"/tempel (bv reinheidsmaatreëls, Sabbat en die gesag om sonde te kan vergewe). Die skrifgeleerdes en priesters se teenwoordigheid in die vertelling voorspel dus potensiële konflik.

Vanaf Markus 2:15 word die konflik tussen Jesus en die godsdienstige leiers progressief meer deel van die vertelling. Aanvanklik vind die konflik tussen Jesus en die skrifgeleerdes en die Fariseërs op 'n indirekte wyse plaas: wanneer Jesus saam met tollenaars en sondaars eet (Mark 2:15), vra die skrifgeleerdes en Fariseërs nie vir Jesus nie, maar vir sy dissipels, hoekom Hy dit doen. Dieselfde indirekte konflik tussen Jesus en die Fariseërs kom in Markus 2:18 voor wanneer Jesus gevra word hoekom Hy en sy dissipels nie vas nie terwyl die Fariseërs dit wel doen.

Die eerste direkte kontak tussen Jesus en die Fariseërs vind plaas wanneer Jesus en sy dissipels die reinheidsmaatreëls rondom die Sabbat oortree (Mark 2:24) en die Fariseërs Jesus daaroor uitvra. Jesus se opmerking, naamlik dat Hy ook oor die Sabbat heers, veroorsaak dat die konflik tussen Hom en die Fariseërs meteens skerp styg: die Fariseërs begin om Jesus dop te hou om te sien of Hy op die sabbat genees sodat hulle Hom kan aankla (Mark 3:2). Wanneer Jesus dit wel doen (die genesing van die man met die verlamde hand) kom die konflik tussen Jesus en die Fariseërs tot uitbarsting: dadelik begin hulle planne smee met die Herodiane om Jesus dood te maak (Mark 3:6). Van hierdie oomblik af konfronteer die Fariseërs (wat nou beskryf word as komende vanaf Jerusalem/die tempel) Jesus sonder uitsondering wanneer Hy hulle ook al rede gee om dit te doen. Ook Jesus se dissipels word nou deel van hierdie konflik wanneer hulle met ongewaste hande eet (Mark 7:2). Interessant is dat waar in Markus 2:15 die Fariseërs hulle vraag tot die dissipels gerig het oor Jesus se optrede, hierdie die vraag aan Jesus gerig word oor sy dissipels se optrede. Aan die einde van die Galilea-gedeelte van die vertelling verhoog die konflik tussen Jesus en die Fariseërs nog meer, in dat die konflik van die Fariseërs se kant af nie meer reaktief is nie, maar proaktief: hulle kom na Jesus toe om met Hom te argumenteer, en vra van Hom 'n teken om te toon waar sy gesag vandaan kom. Jesus kom egter telkens "bo uit" in hierdie gesprekke. In kort: in die Galilea-gedeelte van die vertelling "wen" Jesus in terme van sy konflik met die Fariseërs (soos dit ook die geval was met sy daarstel van die nuwe huishouding). 


\section{Eskatologie en koninkryk in die Markusevangelie}

In die Jerusalem-gedeelte van die vertelling (Mark 11:1-16:7) kry die godsdienstige leiers egter die oorhand in hulle konflik met Jesus. Wanneer Jesus na sy optrede in die tempel leer dat die tempel 'n huis van gebed vir alle nasies behoort te wees (dus inklusief), begin die skrifgeleerdes en priesters na 'n plan soek om Jesus dood te maak (Mark 11:18). Hierdie plan, wat reeds in Markus 3:6 ter sprake was, kry nou momentum. Die hoëpriester, die priesters, skrifgeleerdes en familiehoofde (let op die groeiende getal teenstanders) konfronteer Jesus die volgende dag in die tempel oor die gesag waarmee Hy die dinge doen wat Hy doen (Mark 11:28). Jesus antwoord hulle vraag met 'n teenvraag (Mark 11:29), en vertel die gelykenis van die huurders (Mark 12:1-12) waarin dit duidelik word dat Jesus van oordeel is dat die eienaar (God) die wingerd (tempel) van die huurders (godsdienstige leiers) gaan wegneem oor die wyse waarop hulle na die wingerd omgesien het (die uitsluit van mense op grond van die reinheidskodes). Die hoëpriester, priesters, skrifgeleerdes en familiehoofde besef dat Jesus die gelykenis teen hulle vertel, maar omdat hulle bang vir die skare is laat hulle Jesus nie arresteer nie, maar stuur eerder die volgende dag Fariseërs en Herodiane (kyk weer Mark 3:6) na Jesus om Hom te probeer uitvang (Mark 12:13). Hulle slaag egter nie daarin nie, soos dit ook die geval is met die Sadduseërs se vraag oor die opstanding (Mark 12:18-27) en die skrifgeleerde se vraag oor die gebooie (Mark 12:28-34). Jesus is dus steeds besig om in die konflik van woorde te "wen".

Vanaf Markus14 verander hierdie situasie egter dramaties. Die priesterhoofde en skrifgeleerdes sweer met Judas saam om Jesus te verraai (Mark 14:10-11). Met die hulp van Judas word Jesus gearresteer (Mark 14:4346), deur die hoëpriester, priesterhoofde, skrifgeleerdes en familiehoofde verhoor (Mark 14:53), skuldig bevind aan godslastering (Mark 14:64), voor Pilatus gebring (Mark 15:1-15), en met die hulp van die skare oorgegee om gekruisig te word. Dus: Jesus "verloor", en die godsdienstige leiers "wen".

\subsubsection{Opsomming: Die drie narratiewe storielyne in Markus}

'n Analise van narratiewe tyd in die Markusvertelling skep die indruk dat Jesus se belofte dat die koninkryk naby is en deur Hom tot 'n realiteit gebring sal word, 'n mislukking blyk te wees. Alleen in Galilea is Jesus se vervanging van die tempel met die nuwe huishouding 'n sukses. Ook die dissipels blyk beperkte sukses en insig te toon terwyl hulle nog in Galilea is. Aan die einde van die vertelling het niks egter verander nie: die tempel is nog in een stuk, die tempelowerhede het die geveg gewen, Jesus is dood (en weg), en die sogenaamde nuwe huishouding is vergete. Jesus en sy dissipels het gefaal, en die tempel het gewen. 


\subsubsection{Storietyd in die Markusvertelling}

Petersen (1980b) se narratologiese analise van narratiewe tyd en storietyd in die Markusvertelling was heel waarskynlik die eerste sodanige ondersoek van tyd in die Evangelie ('n ondersoek wat volgens my oordeel nie die nodige erkenning in Markusnavorsing ontvang wat dit verdien nie). Hierdie ondersoek fokus op Markus 13 en Markus 16:7, en neem as vertrekpunt dat in Markus "the storyteller's principal plot device is one of prediction en fulfillment" (Petersen 1980b:155). Volgens Petersen word al die voorspellings wat in Markus gemaak word in die vertelling self vervul, behalwe Markus 16:7. In 'n poging om hierdie rariteit van Markus te verstaan, gaan Petersen van die volgende twee vooronderstellings uit: Eerstens is dit nie moontlik dat die voorspelling van Jesus in Markus 16:7 nie in die vertelling vervul word nie, aangesien dit die verteller se geloofwaardigheid ernstig sal ondermyn. In die tweede plek lê die oplossing van die "probleem" van Markus 16:7 moontlik in ' $n$ lees van die teks wat onderskei tussen narratiewe tyd en storietyd. Met hierdie vooronderstellings as vertrekpunt kom Petersen (1980b:158-160) tot die slotsom dat Markus 13:9-11 gesien kan word as vervulling van die voorspelling in Markus 16:7-8. Omdat Markus 13:9-11 in Galilea afspeel, is die einde van Markus se vertelling dus nie die einde nie, alleen maar 'n nuwe begin. Die Evangelie begin nie alleen in Galilea nie, dit eindig ook in Galilea en begin dan weer in Galilea. In Markus se vertelling, aldus Petersen, word Jerusalem dus deur Galilea "oorwin".

Soos bo reeds genoem is, is die tese van die onderhawige artikel dat wanneer die narratiewe struktuur van Markus ernstig opgeneem word (itv die verskil tussen en gebruik van storietyd en narratiewe tyd), die eskatologie van Markus, sy gebruik van die begrip koninkryk, asook die Seun van die mensuitsprake in die Evangelie vanuit ' $n$ ander perspektief ondersoek kan word. In Markusnavorsing, as voorbeeld, oordeel die meeste navorsers dat die Markus 13 na die gebeure verwys wat sal afspeel voor (of dan net voor) die paroesie (tweede koms) van Jesus, dit wil sê, gebeure wat alleen voorspel word, maar nie in die Markusvertelling in vervulling gaan nie (kyk bv Vorster 1987).

Wanneer die narratiewe struktuur van Markus egter ernstig opgeneem word, en Markus 13 word gelees in terme van die verteller se gebruik van storietyd (in navolging van Petersen), word die moontlikheid geopen om hierdie "voorspellings" in Markus 13 (asook ander "voorspellings" in die vertelling soos bv die Seun van die mens-uitsprake) vanuit 'n ander (en dalk vars) perspektief te analiseer. Die volgende "voorspellings" (proleptiese uitsprake) kom in die Markusvertelling voor wat verband hou met Markus se verstaan van koninkryk en eskatologie:

- uitsprake van Jesus waarin Hy sy dood en opstanding voorspel (Mark $8: 31 ; 9: 31 ; 10: 33-34$ en 14:21); 
- Jesus se "eskatologiese" Seun van die mens-uitsprake (Mark 8:38; 13:26 en 14:62);

- Jesus se uitsprake oor die vernietiging van die tempel (Mark 13:2, ook geïmpliseer in Mark 14:58 en 15:29);

- uitsprake van Jesus dat die huidige geslag die koms van die Seun van die mens sal sien of beleef (Mark 8:38; 9:1, 13:26 en 13:30);

- voorspelling van Jesus in Markus 13, en

- Markus 14:28 en 16:7, die voorspelling van Jesus dat Hy sy dissipels na sy opstanding in Galilea sal ontmoet.

Jesus se voorspellings oor sy komende dood en opstanding (kyk bo) word duidelik in die vertelling vervul. Alhoewel daar, in terme van Markus se narratiewe tyd, na Jesus se dood en opstanding in Markus 8:31; 9:31; 10:3334 en 14:21 verwys word, vind hierdie gebeure, in terme van Markus se storietyd, in Markus 15:37 en Markus 16:6 plaas. Om te bepaal of die res van Jesus se die proleptiese uitsprake ook tot vervulling in die Markusvertelling gaan, vestig ons nou die aandag op 'n analise van Markus $13 .{ }^{20}$

\footnotetext{
${ }^{20}$ Die Wirkungsgeschichte van Markus 13 toon dat die bestudering van hierdie gedeelte meestal fokus op die moontlike bron(ne) waarvan die skrywer gebruik gemaak het, asook die gedeelte se literêre wordingsproses (kyk Vorster 1987:204). Colani, as voorbeeld, was die eerste Nuwe-Testamentikus wat van oordeel was dat Markus in Markus 13 van 'n bestaande apokalips gebruik gemaak het en dit uitgebrei het. Ook die standpunt van Pesch (1968) is welbekend in Markusnavorsing: Markus het van 'n apokaliptiese "pamflet" gebruik gemaak wat aan sy lesers bekend was, en het dit, nadat hy sy evangelie voltooi het, teen sy sin tot sy evangelie bygevoeg op grond van die gewildheid daarvan - al het die "pamflet" tradisies bevat waarin hy nie belang gestel het nie en 'n negatiewe impak op die struktuur van sy evangelie gehad. Ander Markusnavorsers weer is van oordeel dat Markus die tradisies wat agter Markus 13 lê oorgeneem en in sy evangelie ingewerk het om bepaalde beskouinge oor moontlike toekomstige gebeure wat in sy gemeente in omloop was, te korrigeer. Meer onlangs het Balabanski (1997:92-97) die tese verdedig dat Markus, in Markus 13, van 'n Judese orakel gebruik gemaak het om Judese Christene, wat vanaf Jerusalem gevlug het net voor die Joodse Oorlog en by Markus se gemeente in Sirië aangesluit het, te akkommodeer. Wat die ondersoek na die genre van Markus 13 betref, kan die volgende uiteenlopende standpunte genoem word: Markus 13 is 'n apokaliptiese Flugblatt of klein apokalips, 'n voorbeeld van literêre evocatio (Kloppenborg 2005), 'n vertelde toespraak van Jesus (Vorster 1987; kyk ook Marcus 1992), of 'n finale toespraak voor dood ('n afskeidsgesprek; Malina 2002a:54). Wat Markus 13 se literêre funksie in terme van die algehele struktuur van die Evangelie betref, kom ook wyd uiteenlopende standpunte voor. Sommige navorsers oordeel dat Markus 13 die vloei van die vertelling onderbreek (Markus 14:1 wat direk volg op Mark 12:44 blyk die oorspronklike vloei van die vertelling te gewees het), terwyl ander navorsers weer van opinie is dat Markus 13 ' $n$ integrale deel van Markus se plot is en die sleutel is om Markus se evangelie te verstaan (kyk e g, Achtemeier 1986:116). Die fokus van die onderhawige bydrae is die bestudering van die narratiewe funksie van Markus 13 as storietyd, terwyl die vertelling in sy huidige vorm ernstig opgeneem word. Die onderhawige bydrae gaan verder van die vooronderstelling uit dat Markus 13 ' $n$ integrale deel van die vertelling uitmaak en konsistent is ten opsigte van Markus se plot. Markus 13 volg nie alleen struktureel logies op Markus 11-12 nie (met Jesus en die tempel as twee hooftemas), maar is ook essensieel vir die verstaan van die ontsluiting (dénouement) van Markus se plot (vir 'n bespreking van Markus 13 as integrale deel van Markus se plot kyk Balabanski 1997:58-69; Geddert 1989; Bolt 1995:12-13). In die onderhawige analise van Markus 13 word, ten slotte, veral gesteun op die vorige insigte van Lightfoot (1950), Farrer (1951), Smith (1981), Radcliff (1987), Geddert (1989), en, in die besonder, Bolt (1995).
} 


\section{DIE NARRATIEWE FUNKSIE VAN MARKUS 13}

Markus 13 begin met 'n profesie van Jesus met as inhoud die val van die tempel (Mark 13:2), gevolg deur 'n vraag van die dissipels oor die tyd wanneer hierdie gebeure sal plaasvind (Mark 13:4). Die Markaanse Jesus se antwoord op hierdie vraag bestaan uit vier verdere opeenvolgende proleptiese uitsprake (wat Markus van mekaar skei deur die gebruik van vier "tydmerkers"), ${ }^{21}$ gevolg deur 'n "tydsuitspraak" (Mark 13:28-31), en sluit af met 'n kort gelykenis met as inhoud 'n refleksie op die vier proleptiese uitsprake wat die Markaanse Jesus aan die begin van sy antwoord op die vraag van die dissipels aanbied (Mark 13:32-37). Die vier proleptiese uitsprake van Jesus is soos volg: Eerstens sal daar rampe, vervolging en 'n tyd van verdrukking wees (Mark 13:5-23), daarna sal die son verduister (Mark 13:24-25), waarna die Seun van die mens sal verskyn (Mark 13:26), en dan sal al die uitverkorenes bymekaar gebring word (Mark 13:27). In die "tydsuitspraak" (vgl Mark 13:30), en kort gelykenis (Mark 13:32-37) wat volg, stel Jesus dat hierdie dinge nog in die leeftyd van die huidige geslag sal gebeur (Mark 13:30). Omdat niemand presies weet wanneer die Seun van die mens sal kom nie (aand, middernag, met hanekraai of vroeg in die oggend; Mark 13:32), moet die dissipels waaksaam wees sodat hulle nie onkant gevang word wanneer uur aanbreek wanneer die Seun van die mens wel kom nie.

Wanneer Jesus se proleptiese uitsprake wat verband hou met Markus se verstaan van eskatologie en die koninkryk (kyk weer § 2.3) vergelyk word met Jesus se vier proleptiese uitsprake hierbo genoem, verwys Markus 13:527, met die uitsondering van Markus 14:28 en 16:7, na al bogenoemde voorspellings: Markus 13:26 verwys na die eskatologiese koms van die Seun van die mens (en dus ook na Mark 8:38 en 14:62); Jesus se uitspraak oor die val van die tempel kom in Markus 13:2 voor, en in Markus 13:26 en 13:30 vind ons die uitspraak van Jesus dat die huidige geslag nog in hulle leeftyd die koms van die Seun van die mens (Mark 8:38 en 9:1) sal ervaar (sien).

In wat volg sal aangetoon word dat al bogenoemde proleptiese uitsprake (voorspellings) van Jesus wat verband hou met die Markaanse eskatologie en verstaan van die begrip koninkryk - wanneer Markus se gebruik van narratiewe tyd en storietyd in ag geneem word en Markus 13 as storietyd $^{22}$ verstaan word - in die Markusvertelling vervul word. Daar sal ook

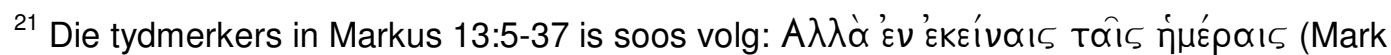

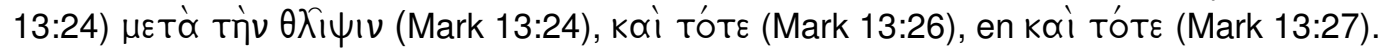

${ }^{22}$ Met ander woorde, dat Markus 13 na gebeure verwys wat kronologies gebeur na die einde van Markus se vertelling, maar op 'n proleptiese wyse as deel van die vertelling se narratiewe tyd aangebied word.
} 


\section{Eskatologie en koninkryk in die Markusevangelie}

aangetoon word dat Markus 14:28 en 16:7 verband hou met die gebeure waarna in Markus 13:27 verwys word.

Die vier tydverwysings in Markus 13:35 (aand, middernag, met hanekraai en vroeg in die oggend) vervul 'n tweevoudige funksie in die Markusvertelling. In die eerste plek lei dit die leser om die lydensnarratief wat volg te verstaan, aangesien die vier tydverwysings in Markus 13:35 ooreenkom met die tydverwysings wat in die lydensnarratief gebruik word (kyk Lightfoot 1950:48-59). Met ander woorde, die Markusverteller het bewustelik, ter wille van die struktuur van sy vertelling, die vier tydverwysings in Markus 13:35 in sy lydensnarratief herhaal. In die tweede plek help die vier tydverwysings in Markus 13:35 die leser om ook die vier proleptiese uitsprake in Markus 13:5-27 te verstaan deur die gebeure wat in hierdie vier proleptiese uitsprake van Jesus beskryf word in verband te bring met die gebeure wat in die lydensnarratief volg. Met hierdie dan as vertrekpunt, lewer ' $n$ analise van Markus 13:5-27 en die lydensnarratief in die Markusvertelling - met die vier tydsaanduidings in Markus 13:35 as sleutel - die volgende resultate:

Die eerste tydverwysing in Markus13:35 is aand ('o $\psi \dot{\varepsilon})$, en hou verband met die gebeure rondom Jesus se laaste maaltyd saam met sy dissipels (Mark 14:17-31) wat, volgens die Markusverteller, in die aand (ó $1 \propto$ @S) plaasgevind het (kyk Mark 14:17). Die laaste maaltyd is egter nie die uur waarna Jesus in Markus 13:32 verwys nie: die dood van die Seun van mens (Mark 14:21) moet nog plaasvind (Mark 15:37), en die aanbreek van die koninkryk is nog steeds 'n futuristiese aangeleentheid. Petrus se verloëning van Jesus (Mark 14:66-72), wat sal gebeur wanneer die haan kraai (Mark 14:30) en verband hou met die derde tydverwysing in Markus 13:35, moet ook nog plaasvind. Ten slotte is daar ook geen inhoudelike verband tussen die gebeure van Markus 14:17-31 en enige van die gebeure soos beskryf deur Jesus in die vier proleptiese uitsprake in Markus 13:5-27 nie.

Markus se tweede tydverwysing in Markus 13:35 is middernag

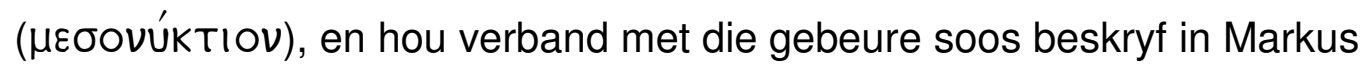
14:32-65: Getsemane, Jesus se gevangeneming, en sy verhoor voor die Sanhedrin. Alhoewel die Markusverteller na geen spesifieke tydsaanduiding verwys wat hierdie gebeure betref nie, is dit duidelik dat dit plaasvind tussen die laaste maaltyd (aand - die eerste tydverwysing van Mark 13:35) en Petrus se verloëning van Jesus (met hanekraai - die derde tydverwysing in Mark 13:35). Belangrik om raak te sien, is dat die tweede tydverwysing in Markus 13:35 verband hou met Jesus se eerste proleptiese uitspraak in Markus 13:527, te wete Markus 13:5-23 (die tyd van groot verdrukking). As sodanig verbind die tweede tydsaanduiding in Markus 13:35 dus Markus 13:5-23 met Markus 14:32-65. Hierdie verband word duidelik wanneer die inhoudelike van 
Markus 14:32-65 en Markus 13:5-23 (Jesus se eerste proleptiese uitspraak) met mekaar vergelyk word. Die volgende parallelle kan aangetoon word:

- Markus 14:34, 38, 41 en Markus 13:5, 9, 23: In die Getsemane-vertelling (Mark 14:32-42) vra Jesus sy dissipels om te waak terwyl Hy gaan bid. By drie geleenthede vind Hy hulle egter aan die slaap, dus nie besig om te waak soos Hy versoek het nie. Dieselfde gebeur in Markus 13:5-23 waar Jesus se dissipels drie keer oproep om waaksaam te wees $\left(\beta \lambda_{\varepsilon}^{\prime} \pi \varepsilon \tau \varepsilon\right.$; Mark 13:5, 9, 23). ${ }^{23}$

- Markus 14:43 en Markus 13:12: In Markus 14:43 word Jesus deur Judas, een van die Twaalf, verraai ( $d$ w s, deur iemand wat deel is van Jesus se nuwe huishouding, en dus 'n broer van Jesus in die sin van Mark 3:33-35). Hierdie gebeure vind sy parallel in Markus 13:12 waar Jesus dit stel dat een broer deur 'n ander oorgelewer sal word om doodgemaak te word.

- Markus 14:43-44 en Markus 13:8: Volgens Markus 14:43-44 is diegene wat Jesus gevangene kom neem het, gestuur deur die priesterhoofde, skrifgeleerdes en familiehoofde, in kort, deur die tempel. Die konfrontasie tussen Jesus en diegene wat Hom kom gevange neem het, is dus 'n botsing tussen "die koninkryk van die nuwe huishouding" en die "koninkryk van die tempel". Hierdie botsing tussen koninkryk en koninkryk vind sy parallel in Markus 13:8 (koninkryk teen koninkryk).

- Markus 14:53-65 en Markus 13:9: In Markus 13:9 (en 11) sê Jesus dat die

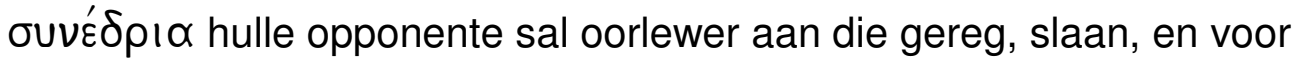

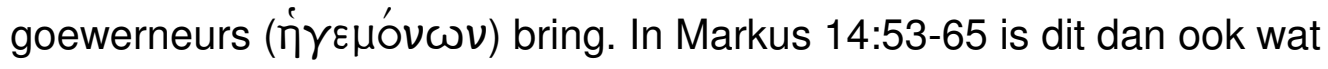
met Jesus gebeur: Hy word gevange geneem, voor die Joodse Raad

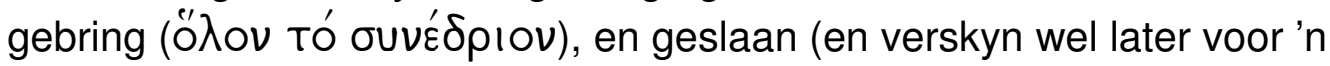
goewerneur, te wete Pilatus).

- Markus 14:60-62 en Markus 13:11: In sy ondervraging deur die hoëpriester word 'n retoriese vraag aan Jesus gestel waarin die enigste antwoord wat Jesus kon gee reeds geïmpliseer word (Mark 14:61). Wat gesê moet word, word dus gegee, 'n parallel van die inhoudelike van Markus 13:11.

\footnotetext{
${ }^{23}$ Hierdie verband tussen Markus 14:34, 38, 41 en Markus 13:5, 9, 23 word verder uitgelig deur Jesus se drie oproepe tot waaksaamheid in Markus 13:33-37. Dit bevestig ook die Markaanse stylvorm om sekere gebeure of mense in 'n serie van drie te beskryf.
} 
- Markus 14:56-57 en Markus 13:22: Die valse getuienis van sommiges (Mark 14:56-57) word vergelyk met die valse profete waarna in Markus 13:22 verwys word.

- Markus 14:45 en Markus 13:14a: Judas se verloëning van Jesus deur middel van 'n soen (Mark 14:45), word vergelyk met Markus 13:14a-die gruwel voor God wat verwoesting saai. ${ }^{24}$

- Markus 14:50-52 en Markus 13:14b: Die vlug van Jesus se dissipels en die nakende jong man (Mark 14:50-52) net na Jesus se gevangeneming word vergelyk met hulle wat die berge invlug nadat hulle die "gruwel wat verwoesting saai" gesien het (Mark 13:14b).

Die tyd van die groot verdrukking, waarna die verteller in Markus 13:5-23 (Jesus se eerste proleptiese uitspraak) verwys het dus in Markus 14:32 'n aanvang neem. Die "uur" van Markus 13:32 het aangebreek - 'n gevolgtrekking wat beklemtoon word deur Jesus se gebed te midde van sy "uur van lyding", te wete dat hierdie uur nie vir Hom moet aanbreek nie, asook sy opmerking teenoor sy dissipels dat die tyd gekom het (Mark 14:41). Die Seun van die mens het egter nog nie gekom nie (Mark 14:62).

Dit bring ons by die derde tydsaanduiding in Markus 13:35, met hanekraai ( $\alpha \lambda \varepsilon k$ ropoф $\omega v^{\prime} \alpha \varsigma$ ), wat met die gebeure in Markus 14:66-71 verband hou. Nog steeds het die Seun van die mens, soos deur Jesus in Markus 13:26 belowe, egter nie gekom nie.

\footnotetext{
${ }^{24}$ Dat hierdie ' $n$ moontlike interpretasie van Markus 13:14a is, kan natuurlik bevraagteken word. Normaalweg word in Markusnavorsing dit waarna Markus 13:14a verwys aan een of ander buite-tekstuele (historiese) referent gekoppel, waarvan die bekendstes Titus, Caligula, Nero, Panias of die hoëpriester is (vir 'n bespreking van hierdie en ander moontlikhede, kyk Balabanski 1997; Kloppenborg 2005). Twee redes kan verskaf word waarom hierdie interpretasie van Markus 13:14a ten minste as 'n moontlikheid gesien behoort word: Eerstens is die uitgesproke uitgangspunt van die onderhawige ondersoek dat Markus as narratief (dus met 'n geskepte tekstuele wêreld of vertelde wêreld), ernstig opgeneem word. Omdat die narratief van Markus ernstig opgeneem word, word die verteller se oproep tot die leser in Markus 13:14, te wete "wie dit lees - moet dit goed begryp" geïnterpreteer as sou hierdie oproep van die leser verwag om "die gruwel wat verwoesting saai" te verstaan soos dit deur die verteller aangebied word. Anders gestel: die leser(s) van Markus het heel waarskynlik 'n bepaalde verstaan van hierdie "gruwel" voorgehou. Markus as verteller vra egter van sy leser(s) om hierdie verstaan op te skort, en goed te begryp waarna hy met hierdie verwysing verwys. Indien die verteller nie van die leser verwag het om hierdie verwysing op 'n besondere manier te verstaan nie, sou die oproep tot die leser nie nodig wees nie. Die feit dat die leser hier egter wel opgeroep word om, wat hierdie saak betref, nou baie mooi te verstaan, is ' $n$ aanduiding dat die verteller ' $n$ ander inhoud aan "die gruwel" wil gee as wat heel waarskynlik die verstaan daarvan in omloop was. Daar kan in hierdie verband ook vermeld word dat daar in Markusnavorsing in elk geval tot dusver geen oortuigende verbinding tussen Markus 13:14 en 'n buite-tekstuele referent gemaak is nie. ' $n$ Laaste opmerking: die keuse hier gemaak beteken nie dat die Markusvertelling a-histories gelees word nie. Aan die einde van die onderhawige bydrae sal daar 'n moontlike sosiohistoriese prentjie van die Markaanse gemeenskap geskets word waarin die verstaan van die eskatologie, die begrip koninkryk in Markus, sowel bogenoemde interpretasie van Markus 13:14, sin sou kon maak.
} 
Dit laat ons met net die laaste tydsaanduiding van Markus 13:35, die môre vroeg ( $\left.\pi \rho \omega^{\prime}\right)$. In die res van Markus se lydensvertelling is daar twee verwysings na vroeg in die more, te wete Markus 15:1 en 16:2. Aangesien die mikrovertelling in Markus 5:1-16:1 die dood van die Seun van die mens as fokus het (Mark 15:44-41; soos prolepties na verwys in Mark 8:31, 9:31 en 10:33-34), en die dood van Jesus eers plaasvind in die negende uur (દ'vóṭ̣ ஸ́pơ), kan die verwysing na vroegoggend in Markus15:1 nie gesien word as die referent van die vierde tydsaanduiding in Markus 13:35 nie. Ook word daar in Markus15:1-16:1 nie verwys na die koms van die Seun van die mens nie.

Die logiese gevolgtrekking is dus dat alleen Markus 16:2 gesien kan word as referent vir die vierde tydsaanduiding in Markus 13:35. Wat het, volgens die Markusverteller, daardie oggend gebeur? Die jongman by die graf vertel aan die vroue dat Jesus van Nasaret, wat gekruisig is, opgestaan het. Die voorspelling van Markus 8:31, 9:31 en 10:33-34 het dus waar geword die Seun van die mens het gekom. Die derde proleptiese uitspraak van Jesus in Markus 13:26 het in vervulling gegaan (asook Mark 8:38 en 14:62). Jesus het opgestaan, Hy is deur God verhoog, sy dood is gevindikeer. En soos belowe is, het die koninkryk in hierdie geslag aangebreek (Mark 8:38, 9:1, 13:26 en 13:30).

Maar wat van die tweede proleptiese uitspraak van Jesus in Markus 13:24-25? Duidelik verwys hierdie proleptiese uitspraak na Markus 15:33, die drie ure van donker tussen die sesde en negende uur en net voor die dood van die Seun van die mens. En die vierde proleptiese uitspraak van Markus 13:27? Hier is die sleutel Markus 14:28 en 16:7. Die herontmoeting tussen Jesus en die dissipels na sy dood in Galilea het plaasgevind. Na hierdie ontmoeting het Petrus verstaan wie Jesus is (contra Mark 8:29). Die dissipels sal nou in staat wees om Jesus teenoor ander valse Christusse te verdedig, en as gevolg van Jesus en sy boodskap, voor geregshowe, sinagoges, goewerneurs en konings gebring word (Mark 13:9-11) - en daarom sal die Seun van die mens Hom nie vir hulle skaam nie (Mark 8:38).

Storietyd in Markus word dus intratekstueel in Markus vervul - storietyd het narratiewe tyd geword.

\section{AFSLUITENDE OPMERKINGS}

In die Markusvertelling is die koninkryk van God, asook die aanbreek van hierdie koninkryk, van kardinale belang. Jesus begin sy openbare optrede deur aan te kondig dat die koninkryk naby gekom het (Mark 1:15), en verkondig dat hierdie koninkryk sal aanbreek wanneer die Seun van die mens 


\section{Eskatologie en koninkryk in die Markusevangelie}

sal kom. Wat meer is, hierdie koninkryk sal aanbreek nog in die leeftyd van die huidige geslag. So verstaan, is eskatologie, koninkryk en koms van die Seun van die mens in Markus nou aan mekaar verbonde. Vir die Markaanse Jesus was die koninkryk die nuwe huishouding van God. Hierdie nuwe huishouding word geopponeer deur die koninkryk van die tempel. In Galilea blyk dit dat die daarstel van hierdie nuwe koninkryk 'n sukses is. Selfs die lede van hierdie nuwe koninkryk (oa die dissipels) blyk suksesvol te wees in die vervanging van die ou koninkryk (tempel) met die nuwe. In Jerusalem blyk egter die omgekeerde te gebeur: die tempel "wen". Die koninkryk van God, soos deur Jesus aangekondig, is nie eers meer naby nie. Dit is so ver as wat dit in die verskiet verdwyn het. Al wat staan is die tempel.

Bogenoemde ondersoek van storietyd en narratiewe tyd in Markus, met as fokus die narratiewe funksie van Markus 13, teken egter 'n ander prentjie. Met die dood van Jesus word die tempel finaal "afgebreek", en die Seun van die mens word gevindikeer deur sy opstanding. Die eskatologiese koninkryk (nuwe huishouding) het oorwin, en is nou 'n werklikheid deur die dissipels wat bereid is om die pad te loop wat Jesus geloop het, beginnende in Galilea soos Jesus. Die koninkryk het die volle sirkel geloop: getuies van die koninkryk het die koninkryk geword. In die Markusvertelling is dit dan ook die eintlike eskatologiese gebeure: die nuwe huishouding wat telkens weer realiseer wanneer dit sigbaar gemaak word. So verstaan, is eskatologie in Markus die koninkryk, en die koninkryk is eskatologie.

Ten slotte vier afsluitende opmerkings. Bogenoemde verstaan van die Seun van die mens-uitsprake ondersteun die standpunt van ander Markusnavorsers wat van oordeel is dat die Seun van die mens-uitsprake in Markus as nie-titulêr verstaan moet word, asook diegene wat van oordeel is dat die paroesie in Markus na God se vindikasie van Jesus deur sy opstanding verwys. Dit kom ook ooreen met die wyse waarop tyd in die eerste-eeuse Mediterreense wêreld verstaan is, naamlik dat 'n gebeure wat op die punt was om te gebeur, ervaar is as 'n soort verlenging van die hede met as beginpunt ook die hede: "If some 'end' were coming soon that is only because of what was under way in the present" (kyk weer Malina 2002b:51).

In die tweede plek wil dit lyk of bogenoemde ondersoek daarop dui dat die Seun van die mens-uitsprake in Markus almal verband hou met Jesus se (aardse) aktiwiteit van die vervanging van die tempel met die nuwe huishouding. Slegs twee Seun van die mens-uitsprake in Markus is nie in die onderhawige ondersoek betrek nie, te wete die in Markus 2:10 and Markus 2:28. Hierdie twee Seun van die mens-uitsprake hou egter ook verband met Jesus se vervanging van die tempel met die nuwe huishouding (koninkryk). In Markus 2:10 word die Seun van die mens se vergewing van sondes 
bevraagteken, en in Markus 2:28 is die Seun van die mens se oortreding van die Sabbatswette in die spervuur. Beide hierdie twee verwysings na die Seun van die mens het dus ook duidelik te make met Jesus se vervanging van die tempel met die koninkryk. Daar kan dus tot die slotsom gekom word dat in Markus die titel Seun van die mens uitsluitlik te make het met Jesus se daarstel van sy nuwe inklusiewe huishouding in die plek van die ou eksklusiewe tempel. Hierdie verband tussen die Seun van die mens-uitsprake en die nuwe huishouding word verder deur die verteller beklemtoon deur die eerste en laaste verwysing na die Seun van die mens in die Markusvertelling (Mark 2:7 en Mark 14:62) te koppel aan Jesus se eerste en laaste interaksie van konflik met die godsdienstige leiers (tempel). Interessant is dat beide hierdie interaksies van konflik die beskuldiging van godslastering as inhoud het (kyk Schröter 2001:57).

Die derde opmerking hou verband met die vraag na metodologie. Bogenoemde ondersoek van eskatologie en koninkryk in Markus bou voort op van my vorige navorsing waarin dieselfde metodologie gevolg is (kyk oa Van Eck 1995). Hierdie metodologie het in 'n onlangse bydrae van Schröter (2001) ondersteuning gevind. Die ooreenkoms tussen my metodologiese vertrekpunte en die van Schröter word duidelik wanneer daar na die volgende opmerkings van Schröter gekyk word: Nadat Schröter wys op die metodologiese tekorte van die vorm- en redaksie-kritiese benaderings as "not taking into account sufficiently the insight that the Gospel of Mark must be seen as a coherent literary work with a narrative structure" (Schröter 2001:35), stel hy oor die Markusvertelling die volgende:

The activity of Jesus is mainly located in Galilee, whereas Jerusalem appears as a hostile place. The narrative world is comprised further of a circle of persons, who are either in a friendly or an unfriendly relationship with the main character of Jesus. It is obvious, therefore, that in both concepts (the concepts kingdom of God and son of man - EvE) the activity of a concrete person within a particular narrative world is designated. This must be kept in view, because it leads to the consequence that the designations applied to the main character have to be interpreted in connection with the narrated events.

(Schröter 2001:46; my beklemtoning)

Uit hierdie aanhaling is die ooreenkoms in metodologie tussen my en Schröter duidelik. Wanneer Schröter egter inhoud aan die begrip "Seun van die mens" (soos deur Markus aangebied) gee, kom hy tot ' $n$ totaal tot 'n ander slotsom as die in die onderhawige bydrae ( $\mathrm{d} \mathrm{w} \mathrm{s}$, dieselfde metodologiese vertrekpunt 


\section{Eskatologie en koninkryk in die Markusevangelie}

maar verskillende konklusies). "Seun van die mens" in Markus word gebruik as 'n honorêre titel "to depict Jesus a representative of God's final judgment at the end of time" (Schröter 2001:61). Schröter baseer hierdie gevolgtrekking op twee oortuigings. Eerstens koppel Mark 13:26-27 die koms van die Seun van die mens op 'n eksplisiete wyse aan die koms van die Seun van die mens in Daniël 7:13-14. Daniël 7:13-14 (soos 1 Henog 46, 48, 69, 71 en 4 Esra 13) verwys na 'n eskatologiese figuur wat aan die einde van die tyd sal verskyn, dus so ook Markus 13:26-27. Tweedens kan die koms van die Seun van die mens in Markus nie na iets anders verwys as God se finale oordeel aan die einde van die tyd nie, aangesien ander "Christian texts themselves are evidence for the use of this expression as a description of God's final envoy" (Schröter 2001:61).

Die vraag in die onderhawige narratologiese ondersoek is nie of die verteller in Markus 13:26-27 van Daniël 7 gebruik gemaak het nie (die verteller het heel waarskynlik), maar die wyse waarop die Markusverteller Markus 13:26-27 funksioneel deel van sy plot maak. Die uitgangspunt is dus dat die vertelling as eenheid ernstig opgeneem word - 'n vertrekpunt waarmee Schröter saamstem. 'n Konsistente toepassing van hierdie uitgangspunt het tot bogenoemde slotsom gelei dat die Markusverteller, deur middel van Markus 13:35, die passievertelling en Markus 13:5-27 as parallelle tekste aanbied. Hierdie lees van Markus 13:5-27 het dit ook moontlik gemaak om tot die gevolgtrekking te kom dat in Markus die verwoesting van die tempel (Mark 13:2) sal plaasvind wanneer die Seun van die mens kom (Mark 13:26), 'n koms wat deur Markus beskryf word as die vindikasie van Jesus deur God met sy opstanding - 'n koms van die Seun van die mens wat die tempel finaal met die nuwe huishouding vervang en die teenwoordige koninkryk van God as 'n eskatologiese gebeure beklemtoon. Die koninkryk van God word dus in Markus as 'n teenwoordige eskatologiese gebeure (entiteit) aangebied, en nie as 'n eskatologiese gebeure wat eendag in die toekoms sal realiseer wanneer die Seun van die mens weer sal kom nie.

Die vierde en laaste opmerking hou verband met die moontlike sosiohistoriese omstandighede van die Markaanse gemeente waarbinne bogenoemde verstaan van die Markusvertelling sin sou kon maak. Die Markaanse gemeente was heel waarskynlik iewers in Noord-Galilea (of SuidSirië) gesitueer, en die datum van skrywe heel waarskynlik net na die val van die tempel (circa 72 nC; ${ }^{25}$ kyk Van Eck 1995:376-402; 2000:974-973-1008).

\footnotetext{
${ }^{25}$ Vir 'n bespreking van die verskillende moontlikhede ten opsigte van die plek en tyd van skrywe van Markus, kyk Van Eck (2000:973-1008). 'n Grondige en resente bydrae ten opsigte van die moontlike tyd van skrywe van Markus, waarvan kennis geneem kan word, is die van Kloppenborg (2005:419-450).
} 
Vir die Markaanse gemeente was die val van die tempel as uitkoms van die Joodse Oorlog (66-70 $\mathrm{nC}$ ) heel waarskynlik 'n teleurstellende en traumatiese gebeure wat verskeie vrae onbeantwoord gelaat het. Die Joodse Oorlog is deur hierdie gemeenskap as ' $n$ apokalipties-eskatologiese gebeure verstaan dit het die hoop laat opvlam dat die oorlog 'n einde aan vreemde oorheersing (vgl Mark 8:29) sou bring, en dat die koninkryk van God daarna sou aanbreek. Die uitkoms van die gebeure rondom $66-70 \mathrm{nC}$ is egter nie wat hulle verwag het nie. Die tempel was verwoes, en geen koninkryk van God was sigbaar nie. Met hierdie omstandighede en onbeantwoorde vrae in die oog vertel Markus sy storie van Jesus aan die gemeente. Vir die gemeente behoort die val van die tempel nie 'n probleem te wees nie, aangesien Jesus reeds baie vroeër die tempel met die nuwe huishouding - wat hierdie gemeente behoort te beliggaam - vervang het. In die tweede plek poog Markus om bestaande eskatologiese verwagtinge in die gemeente te korrigeer. Die Joodse Oorlog was nie die eskatologiese gebeure waarop hulle gehoop het om die koninkryk van God in te lei nie. Die eskatologiese gebeure wat die koninkryk van God 'n realiteit gemaak het is die Jesusgebeure: die nuwe inklusiewe huishouding, Jesus se lyding, sy dood (die eintlike verwoesting van die tempel) en sy opstanding (die koms van die Seun van die mens). God se eskatologiese koninkryk was daarom nou 'n aangebroke realiteit, en om deel te wees van hierdie koninkryk beteken die bereidwilligheid om te ly soos Jesus gely het. Om hierdie boodskap te legitimeer, maak die verteller (in Markus 13) van 'n bestaande apokaliptiese tradisie (apokaliptiese Flugblatt/klein apokalips) gebruik wat heel waarskynlik in een of ander vorm aan sy lesers bekend was, en herinterpreteer dit om aan te toon dat die eskatologiese gebeure waarop gehoop is in Jesus se lewe, dood en opstanding aangebreek het ${ }^{26}$. Die Seun van die mens het gekom. Dit is wat die leser (Markus se gemeente) moet verstaan (Mark 13:14).

\section{Literatuurverwysings}

Achtemeier, P J 1986. Mark. Philadelphia, PA: Fortress. (Proclamation Commentaries.)

Adams, E 2005. The coming Son of man in Mark's gospel. Tyndale Bulletin 56(2), 39-61.

Aune, D E 1975. The significance of the delay of the parousia for early Christianity, in Hawthorne (ed), Current issues in Biblical and patristic interpretation: Studies in honor of Merrill C Tenney, 87-109. Grand Rapids, Ml: Eerdmans.

\footnotetext{
${ }^{26}$ Bogenoemde verstaan van die funksie van die apokaliptiese genre van Markus 13 is die van Aune (1986:87), wat die funksie van die apokaliptiese genre soos volg definieer: "(a) to legitimate the transcendent authorization of the message, (b) by mediating a new actualization of the original revelatory experience through literary devices, structures and imagery, which function to 'conceal' the message which the text 'reveals', so that (c) the recipients of the message will be encouraged to modify their cognitive and behavioral stance in conformity with transcendent perspectives (my beklemtoning).
} 


\section{Eskatologie en koninkryk in die Markusevangelie}

Aune, D E 1986. The apocalypse of John and the problem of genre, in Collins, A Y (ed), Early Christian apocalyptism: Genre and social setting, 65-96. Decatur, GA: Scholars Press. (Semeia 36.)

Balabanski, V 1997. Eschatology in the making: Mark, Matthew and the Didache. Cambridge: Cambridge University Press. (Society for New Testament Studies Monograph Series 97.)

Bauckham, R J 1980. The delay of the parousia. Tyndale Bulletin 31, 3-36.

Bauckham, R J 1983. Jude, 2 Peter. Waco, TX: Word. (WBC 50.)

Best, E 1970. Discipleship in Mark: Mark 8:22-10:52. Scottish Journal of Theology 23, 323-337.

Best, E 1983. Mark: The Gospel as story. Edinburgh: T \& T Clark.

Bietenhard, H 1982. Der Menschensohn - ho huios to anthropoi: Sprachliche und religionsgeschichtliche Untersuchungen zun einem Begriff der synoptichen Evangelien, I, in Aufstieg und Niedergang der Römischen Welt, II.25.1.265-350.

Bolt, P G 1995. Mark 13: An apocalyptic precursor to the passion narrative. The Reformed Theological Review 54, 10-33.

Bornkamm, G 1951. Die verzögerung der parusie: Exegetische bemerkungen zu zwei synoptischen texten, in Schmauch, W (Hrsg), Memoriam E Lohmeyer, 116126. Stuttgart: Verlag Katholisches Bibelwerk.

Bultmann, R 1931. Die geschichte der synoptischen Tradition. Göttingen: Vandenhoeck \& Ruprecht.

Bultmann, R 1948. Theologie des Neuen Testaments. Tübingen: Mohr.

Burkett, D 1999. The Son of man debate: A history and evaluation. Cambridge: Cambridge University Press. (SNTS Monograph Series 107.)

Carrol, J T 2000. The parousia of Jesus in the synoptic Gospels and Acts, in Carrol, J $T$ et al (eds), The return of Jesus in early Christianity, 5-45. Peabody, MA: Hendrickson.

Casey, M 1979. Son of man: The interpretation and influence of Daniel 7. London: SPCK.

Casey, M 1987. General, generic and indefinite: The use of the term "Son of man" in Aramaic sources and in the teaching of Jesus. JSNT 29, 17-43.

Casey, M 1991. Method in our madness, and madness in our methods: Some approaches to the Son of man problem in recent scholarship. JSNT 42, 17-43.

Casey, M 1994. The use of the term bar (e)nash(a) in the Aramaic translations of the Hebrew Bible. JSNT 54, 87-118.

Chatman, S 1978. Story and discourse: Narrative structure in fiction and film. Ithaca, NY: Cornell University Press.

Collins, A Y 1996. Cosmology and eschatology in Jewish and Christian apocalypticism. Leiden: Brill. (JSJ Suppl 50.)

Conzelmann, H 1959. Geschichte und Eschaton in Mark 13. ZNW50, 210-221.

Conzelmann, H 1960. The theology of St Luke. London: Faber.

Crossan, J D 1991. The historical Jesus: The life of a Jewish Mediterranean Jewish peasant. San Francisco, CA: Harper.

Cullmann, O 1971. The Christology of the New Testament. London: C A M Hall.

Dewey, J 1980. Marcan public debate: Literary technique, concentric structure, and theology in Mark 2:1-3:6. Chico, CA: Scholars Press. 
Dodd, C H 1936. The parables of the kingdom. London: Nesbit \& Co.

Duling, D C 1994. The Gospel of Mark: A mysterious apocalyptic drama, in Duling, D C \& Perrin, N, The New Testament: Proclamation and paranesis, myth and history, 295-327. Orlando, FL: Harcourt Brace College Publishers.

Ehrman, B D 1999. Jesus: apocalyptic prophet of the new millennium. New York: Oxford University Press.

Farrer, A 1951. A study in Mark. London: Dacre.

Fitzmeyer, J A 1984. Another view of the "Son of man" debate. JSNT 4, 58-68.

Fowler, R M 1981. Loaves and fishes: The function of the feeding stories in the Gospel of Mark. Chico, CA: Scholars Press.

France, R T 1971. Jesus and the Old Testament: His application of Old Testament passages to himself and his mission. London: Tyndale.

France, R T 1990. Divine government: God's kinship in the Gospel of Mark. London: SPCK.

France, R T 2002. The Gospel of Mark: A commentary on the Greek text. (Grand Rapids, MI: Paternoster. (NIGNT.)

Geddert, T J 1989. Watchwords: Mark 13 and Markan eschatology. Sheffield: JSNT. (JSNT Suppl.)

Grässer, E 1977. Das problem der Parusieverzögerung in der synoptischen Evangelien und in der Apostelgeschichte. New York: De Gruyter.

Herzog, W R 2000. Jesus, justice and the reign of God: A ministry of liberation. Louisville, KY: Westminister John Knox.

Hurtado, L W 2005. Lord Jesus Christ: Devotion to Jesus in earliest Christianity. Grand Rapids, MI: Eerdmans.

Kelber, W H 1974. The kingdom of Mark: A new place and a new time. Philadelphia, PA: Fortress.

Kingsbury, J D 1989. Conflict in Mark: Jesus, authorities, disciples. Minneapolis, MN: Fortress.

Kloppenborg, J S 2005. Evocatio deorum and the date of Mark. JBL 124(3), 419-450. Lightfoot, R H 1950. The gospel message of St Mark. Oxford: Clarendon.

Lindars, B 1983. Jesus Son of man: A fresh examination of the Son of Man sayings in the Gospels in light of recent research. London: Society of Promoting Christian Knowledge.

Loba-Mkole, J-C 2003. "Son of man" and exegetical myths. HTS 59(3), 837-858.

Lohmeyer, E 1936. Galiläa und Jerusalem. Göttiingen: Vandenhoeck \& Ruprecht.

Lohmeyer, E 1942. Kultus und Evangelium. Göttiingen: Vandenhoeck \& Ruprecht.

Malbon, E S 1982. Galilee and Jerusalem: History and literature in Marcan interpretation. CBQ 44, 242-255.

Malbon, E S 1986. Narrative space and mythic meaning in Mark: New voices in biblical studies. San Francisco, CA: Harper.

Malina, B J 1989. Christ and time: Swiss or Mediterranean? CBQ 51, 1-31.

Malina, B J 1991. Reading theory perspective: Reading Luke-Acts, in Neyrey, J H (ed), The social world of Luke-Acts: Models for interpretation, 1-23. Peabody, MA: Hendrickson.

Malina, B J 2001. The social gospel of Jesus: The kingdom of God in Mediterranean perspective. Minneapolis, MN: Fortress. 


\section{Eskatologie en koninkryk in die Markusevangelie}

Malina, B J 2002a. Exegetical eschatology, the peasant present and the final discourse genre: The case of Mark 13. BTB 32(2), 49-59.

Malina, B J 2002b. Social-scientific models on historical Jesus research, in Stegemann, W, Malina, B J \& Theissen, G (eds), The social setting of Jesus and the Gospels, 3-26. Minneapolis, MN: Fortress.

Marcus, J 1992. The Jewish war and the Sitz im Leben of Mark. JBL 111(3), 441462.

Marshall, I H 1992. The parousia in the New Testament and today, in Wilkins, M J \& Paige, T (eds), Worship, theology and ministry in the early church: Essays in honor of Ralph P Martin, 194-211. Sheffield: JSNT. (JSNT Suppl 87.)

Marxsen, W 1959. Der Evangelist Markus: Studien zur Redaktionsgeschichte des Evangeliums. Göttiingen: Vandenhoeck \& Ruprecht.

Montgomery, J A 1927. A critical and exegetical commentary on the book of Daniel. Edinburgh: T \& T Clark. (ICC.)

Perrin, N 1966. The Son of Man in ancient Judaism and primitive Christianity: A suggestion. Biblical Research 11, 17-28.

Pesch, R 1968. Naherwartungen: Tradition und Redaktion in Mk 13. Düsseldorf: Patmos. (KBANT.)

Petersen, N R 1980a. The composition of Mark 4:1-8:26. HThR 73, 185-217.

Petersen, N R 1980b. When is the end not the end? Literary reflections on the ending of Mark's narrative. Interpretation 34, 151-166.

Radcliffe, T 1987. The coming of the Son of Man: Mark's gospel and the subversion of "the apocalyptic imagination", in Davies, B (ed), Language, meaning and God: Essays in honor of Herbert McCabe, 176-189. London: Chapman.

Rhoads, D \& Michie, D 1982. Mark as story: An introduction to the narrative of a gospel. Philadelphia, PA: Fortress.

Schröter, J 2001. The Son of man as the representative of God's kingdom: On the interpretation of Jesus in Mark and Q, in Labahn, M \& Schmidt, A, Jesus, Mark and Q: The teaching of Jesus and its earliest records, 34-68. Sheffield: Sheffield Academic Press. (JSNTS Suppl Series 214.)

Schweitzer, A 1954. The quest of the historical Jesus: A critical study of its progress from Reimarus to Wrede. London: A \& C Black.

Shepherd, M B 2006. Daniel 7:13 and the New Testament Son of man. WTJ 68, 99111.

Smith, M 1981. The composition of Mark 11-16. HeyJ 22(4), 364-375.

Svendlund, G 1974. Aramaic portions of the Pesiqta de Rab Kahana. Uppsala: Almqvist \& Wiksell.

Tannehill, R C 1980. The Gospel of Mark as narrative Christology. Semeia 16, 57-95.

Tannehill, R C 1983. The disciples in Mark: The function of narrative role. JR 75, 386-405.

Van Aarde, A 2002. Die uitdrukking "seun van die mens" in die Jesus-tradisie: 'n Ontwikkeling vanaf 'n landbou-omgewing na die wêreld van skrifgeleerdes. HTS 58(4), 1625-1653.

Van Aarde, A G 2004. Jesus and the Son of Man: A shift from the "Little tradition" to the "Great tradition". Ephemerides Theologicae Lovanienses 80(4), 423-438. 
Van Eck, E \& Van Aarde, A G 1989. A narratological analysis of Mark 12:1-12: The plot of the Gospel of Mark in a nutshell. HTS 45(4), 778-800.

Van Eck, E 2000. A Sitz for the Gospel of Mark? A critical reaction to Bauckham's theory on the universality of the Gospels. HTS 56(4), 973-1008.

Van Eck, E 1995. Galilee and Jerusalem in Mark's story of Jesus: A narratological and social-scientific reading. Pretoria: Kital. (HTS Suppl 7.)

Van lersel, B 1988. Reading Mark. Collegeville, MN: Liturgical.

Vermes, G 1967. The use of bar nash/bar nasha in Jewish Aramaic, in Black, M (ed), An Aramaic approach to the Gospels and Acts, 310-328. Oxford: Oxford University Press.

Vorster, W S 1983. Die Evangelie volgens Markus, in Du Toit, A B (red), Handleiding by die Nuwe Testament, Band IV: Die Sinoptiese evangelies en Handelinge: Inleiding en teologie, 109-155. Pretoria: NGKB.

Vorster, W S 1987. Literary reflection on Mark 13:5-37: A narrated speech of Jesus. Neotestamentica 21, 203-224.

Weiss, J 1971. Jesus' proclamation of the kingdom of God. London: SCM.

Wright, N T 1996. Jesus and the victory of God: Christian origins and the question of God, Vol II. London: SPCK.

Wright, N T 2001. Mark for everyone. London: SPCK. 